招待論文

\title{
エネルギー使用量を考慮した社会基盤施設の新しい設計法 A NEW INFRASTRUCTURE DESIGN METHOD CONSIDERING RESTRICTION OF ENERGY CONSUMPTION
}

\author{
松尾稳 1 - 本城勇介 ${ }^{2} \cdot$ 杉山郁夫 $^{3}$ \\ Minoru MATSUO, Yusuke HONJO and Ikuo SUGIYAMA
}

\author{
1正会員 工博 名古屋大学 工学部 理工科学研究センター長 土木学会会長 \\ （广464-01 名古屋市千種区不老町） \\ 2正会員 Ph.D. 岐阜大学 工学部 土木工学科 助教授 \\ （テ501-11 岐阜市柳戸1-1） \\ 3正会員 工修 株式会社日建設計 土木事務所 設計部長 \\ （テ541 六阪市中央区高麗橋4-6-2）
}

Key Words: infrastructure design, environmental economics, energy consumption, sustainable development, carbon serviceability, design method, $\mathrm{CO}_{2}$ emission

\section{1. まえがき}

本研究の目的は, 20 世紀末の現在, これから人類が 直面するであろう資源・環境の制約の問題を踏まえ，こ れを社会基盤施設の設計と言う観点から捉えたときの， 新しいアプローチの仕方を模索し, 試案を提示すること にある. 我々は, 今日の根本的な問題を次のように認識 している.

産業革命以来, 特に 20 世紀の初頭, そして第 2 次世 界大戦以後, 近代の技術と科学の発展と普及に支えられ， 世界の物的生産, 消費は急激に拡大し, 人口も50年ご とに倍増するという著しい増加を示した. これは，人類 の歴史の中で未曾有の急激な変化であることは間違いな い.もちろんその背後には，化石然料など地球の長い歴 史の中で蓄積された資源の大量の消費と, 温室勃果ガス の発生に代表される環境負荷の著しい増大があった.

このような，著しい経済成長を実現したのは，資本主 義経済社会体制であり，またこの中で発展を遂げた科学 技術の応用による生産性の著しい向上であった。このシ ステムは，人類の物的な欲望を刺激することにより，シ ステム全体の効率化を極限まで追求することを可能にし， またそれを強いるシステムであった. しかし，一方でこ
のシステムでは拡大と成長が前提とされ, 成長の停止を 許容することのできないシステムでもある.このシステ ムではまた，資源・環境がその成長の制約となることは 前提とされていない。

一方で，このような急激な成長は全世界で一様に起 こったのではなく，先進工業諸国と言われる一部の北の 国々で先行して起こった変化であった. 現在では, 最も 豊かな国と貧しい国の一人当たりの所得格差は 100 倍 以上にも達している。このような著しい経済的格差は, 倫理的にも問題であるが, 世界全体の経済・社会システ ムの安全性の上でも見過ごせない問題である.このよう な格差を是正し，国際社会を安定な状態に維持するため には，これら発展途上国の経済・社会的な成長のため， 今後とも相当程度の経済成長を達成する必要性がある.

先に言及したように，今日の成長を可能にした資本主 義経済システムと並ぶもう一つの要素は, 科学技術で あった.これも経済システムの枠組みの中で，経済的な 効率性を追求することで著しい進歩を遂げ，その結果細 分化, 専門分科が著しい.このような枠組みの中では, 個別の分野の科学技術は, 社会システム全体の中で求め られている目的を把握し，これに整合する形で自身の個 別分野を発展させて行くことが困難になりつつある. 科 
学技術においても総合化が必要であり, 個々の分野で, 全体を視野に入れた調和のとれた目的の設定が重要な課 題である.

資源・環境問題を考えるに当たっては，一部のいわゆ る「環境主義者」が唱えるように，ただ昔の「シンプル ・ライフ」にかえればよいと言った解決はあり得ない， 今日の人口は既に 20 世紀半ばの 2 倍以上に達しており， これを維持して行くだけでもそのような選択はあり得な いからである. 今日では, この問題解决のため, 新しい パラダイムが求められている，それは，資源と環境の長 期的な保全を可能にする社会システムと，これを支える 調和のとれた新しい科学技術の構築を目指すものである 必要がある.

このような新しいパラダイムを視野に入れ，我々は今 後必要とされる経済開発を可能にしつつ, エネルギー使 用量や環境負荷の低減を考慮した社会基盤施設の設計法 に関する新しいアプローチを提案するのである．新しい 社会基盤施設の計画・設計法とは，現在までに得られて いる知識の総合化であり, 人間活動と自然システムの調 和のとれた意思決定手法のことである.

\section{2. 研究の背景}

\section{（1）人口・資碈・エネルギーと偯境負荷}

現在各方面で議論されている種々の環境問題の背景に は, 周知のように人類の爆発的な人口増大, これと合い まった工業文明の進歩による資源とエネルギーの大量使 用の問題がある. 本節では，この点を基本的な統計を参 照しながら簡単に指摘する.

龱-1は，1991年に厚生省人口問題研究所より発表 された「世界の人口の推移」である1)。これは種々ある この種の推計の内, 中位の部類に属する推計と思われる が，これによれば1950年に約 25 億人の人口が，1990年 に53億人となり，2050年には約 100 億人になると言うま さに爆発的な人口増加を示している．また，その増加の ほとんどが途上国で起こることにも注意する必要がある。

龱一2は，世界のエネルギー利用の変遷を示したもの である. 第二次世界大戦後の大量生産・大量消費の進展 に伴いこれもまた人口増加以上の爆発的なエネルギー消 費が起こっていることが分かる2).またその主役は，石 油・石炭・天然ガス等の言わゆる化石燃料である.なお, 統計には示されないが，一人当たりのエネルギー消費量 には世界で著しい格差があることにも注意を要する．た とえば，全世界人口の5.2\%を占める北米のエネルギー消

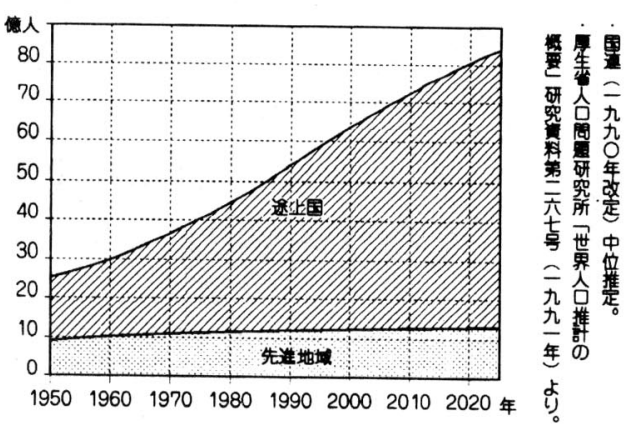

园-1世界の人口の推移1)

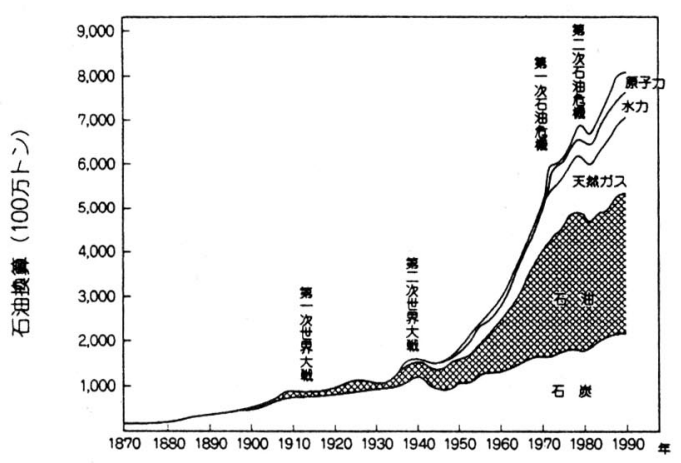

冈-2 世界のエネルギー利用の推移2)

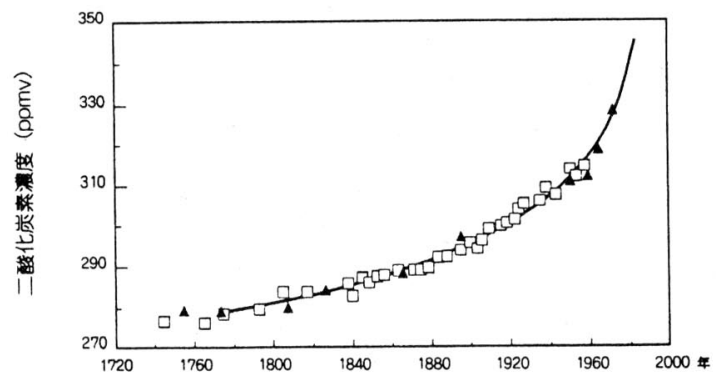

龱-3 大気中の二酸化炭素の変動2)

費量は全世界のエネルギー消費量の $27.5 \%$ であるのに対 し，人口の $12.2 \%$ を占めるアフリカのそれは僅か $2.8 \%$ に過ぎない，今後途上国で開発が進めば，エネルギー使 用量は, さらに増加することは確実であろう. 
表ー 1 世界のエネルギー資源埋葴量2)

\begin{tabular}{|c|c|c|c|c|c|}
\hline & & 油 & 天然ガス & 石 & ラ \\
\hline \multicolumn{2}{|c|}{$\begin{array}{c}\text { 確認可採埋蔵量 } \\
(\mathrm{R})\end{array}$} & $\begin{array}{l}\text { '93 年 } 1 \text { 月 } 1 \text { 日現在 } \\
997.041 \text { 百万代-しl } \\
\text { 全世界 }\end{array}$ & $\begin{array}{l}\text { 93 年 } 1 \text { 月 } 1 \text { 日現在 } \\
138 \text { 北 } \text { m }^{3} \\
\text { 全世界 }\end{array}$ & $\begin{array}{l}' 90 \text { 年末 } \\
10.392 \text { 億ト }\end{array}$ & $\begin{array}{l}89 \text { 年 1月 } 200 \text { 万ト } \\
\$ 80 / \mathrm{kgU以下} \\
139 \text { 万ト } \\
\$ 80 \sim \$ 130 / \mathrm{kgU} \\
61 \text { 万ト\% }\end{array}$ \\
\hline \multicolumn{2}{|c|}{ 年 生 $_{(\mathrm{P})}^{\text {(注 } 2)}$} & $\begin{array}{l}92 \text { 年 } \\
60.029 \text { 千b/d }\end{array}$ & $\begin{array}{l}92 \text { 年 } \\
216 \text { 百億 } \mathrm{m}^{3}\end{array}$ & $\begin{array}{l}90 \text { 年 } \\
47.5 \text { 億ト }\end{array}$ & $\begin{array}{l}\text { '91 年 } \\
2.7 \text { ケト } \\
\text { (共産圈を除く) }\end{array}$ \\
\hline \multicolumn{2}{|c|}{ 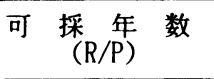 } & $\begin{array}{l}\text { '92 年 } \\
\text { 全世界 }\end{array}$ & $\begin{array}{l}\text { 92 年 } \\
\text { 全世界 }\end{array}$ & 全世界 & $\begin{array}{l}74 \text { 年 } \\
\text { （共産圈を除く） }\end{array}$ \\
\hline \multirow{2}{*}{ 出 所 } & （注 1) & $\begin{array}{l}\begin{array}{l}0 \text { il \& Gas Journal } \\
\text { (December 28. } 1992)\end{array} \\
\end{array}$ & $\begin{array}{l}\text { 0il \& Gas Journal } \\
\text { (December 28. 1992) }\end{array}$ & \multirow{2}{*}{$\begin{array}{l}\text { 世界エネルギー会議 } \\
\text { ('92 年) }\end{array}$} & \multirow{2}{*}{$\begin{array}{l}\text { OECD/NEA/IAEA } \\
\text { （' 92年） }\end{array}$} \\
\hline & （注 2） & $\begin{array}{l}\text { 0il \& Gas Journal } \\
\text { (March 8. 1992) }\end{array}$ & $\begin{array}{l}\text { Oil \& Gas Journal } \\
\text { (March 8. 1992) }\end{array}$ & & \\
\hline
\end{tabular}

は，研究者の間でも多くの議論があるが，最近のIPCC （気候変動に関する政府間パネル）の報告では，人為的

表-2 世界の主要金属元素埋蔵量 ${ }^{2)}$

\begin{tabular}{|c|c|c|c|c|c|}
\hline 金属㾞源 & \multicolumn{2}{|c|}{ 世界の埋蔵量 (R) } & \multicolumn{2}{|c|}{ 世界の年間生産最 (P) } & 可採年数 $(\mathrm{R} / \mathrm{P})$ \\
\hline 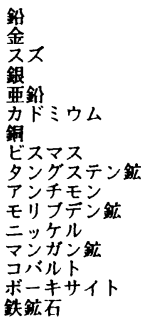 & $\begin{array}{r}120,000 \\
49,400 \\
6,000 \\
420,000 \\
295,000 \\
970 \\
574,000 \\
250,000 \\
3,438 \\
4,695 \\
11,810 \\
111,586 \\
3,538 \\
8,340 \\
24,500 \\
229,000\end{array}$ & 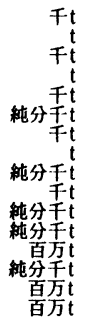 & $\begin{array}{c}5,586.0 \\
2,060 \\
223.2 \\
14,200 \\
7,187.5 \\
20,989 \\
10,605.9 \\
3,200 \\
44,008 \\
52,537 \\
99,100 \\
891.1 \\
23,872 \\
38,512 \\
110,650.5 \\
906\end{array}$ & 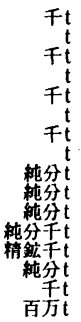 & $\begin{array}{l}21 \text { 年 } \\
24 \\
27 \\
30 \\
41 \\
46 \\
54 \\
78 \\
78 \\
89 \\
119 \\
125 \\
148 \\
217 \\
221 \\
253\end{array}$ \\
\hline
\end{tabular}

表－1には，1993年に通産省から発表された主たる エネルギー資源の埋藏量に関する基本值を示した ${ }^{3)}$. 可 採年数を見ると石油 45 年, 天然ガス 60 年, 石炭 200 年と なっている. 我々が数億年の地球の歴史の中で固定され てきた太陽エネルギーをいかに急激に消費しようとして いるかが分かる.

表一2は，1991年現在で推定された主要金属元素の 可採年数の推定値を示した ${ }^{2)}$. いくつかのものは, 年間 生産量が世界埋蔵量の数パーセントに達すると言う異常 な状態で，これもまた急激な消費であることが理解され る.

以上のようなエネルギーと資源の大量消費は，資源の 枯渴と言う意味でも大変大きな問題であるが, 同時に温 暖化に代表される地球環境に著しい変化をもたらすと言 う意味でも極めて梁刻な事態となっている．目一－3は， 18世紀末から今日までの大気中の二酸化炭素濃度の変化 を示している2．極地の水に閉じこめられた古大気の分 析より，五千年〜一万年前から産業革命頃までは，大気 中の二酸化炭素濃度は280 290ppmであったことが確 認されており，著しい増加を示していることが分かる.

二酸化炭素の増加と地球の温暖化の因果関係について 温暖化説を採るに至っている4).

以上示した統計值は，この種のものとしてはごく一部 であるが，それでもなお生物としての我々が，子孫の生 存の可能な限りの延長を，今真剣に考えるべき時である ことを教えるのに十分であろう.

\section{（2）エネルギー使用量の低洼を考慮した社会基路旅 の建設}

前節で述べたような地球規模での環境問題を踏まえ 1992年2月にリオ・デ・ジャネイロで開催されたのが， 地球環境サミットであった5). そこで採択された宣言 「アジェンダ $21 」$ 」中心的な概念は「持続可能な開 発」（sustainable development）であった. 環境破壊 を引き起こさない環境容量範囲にいて, 可能な限りの経 済成長を成し遂げるというこの概念は，何人にも反対す ることの出来ない理想的な概念である. しかしそもそも 環境の保全（susutain）と経済の開発（development） はトレードオフ関係にある対立概念である.人口の約 2 割を占める先進諸国でエネルギーの約 8 割を消費してい るという現実がある. 途上国の経済開発に伴い，エネル ギ一使用量は増大し，それは必然的に環境負荷を増大さ せることは必至である.「持続可能な開発」と言う言葉 は, 環境の保全を望む北と, 経済開発を望む南の国々の, 両者を満足させるための㝃弁にすぎないと指摘する向き もあるくらいである.

このような観点に立てば，「持続可能な開発」の達成 は, 絶望感に襲われ, 気力が萎えるほどの困難さを感じ させる. しかし我々は何かをしなければならない. 上述 の困難さを認識した上で, 我々に可能なことから, 具体 的に行動を始めなければならないと考える.

環境問題を考元るときの一つの基本的な概念は，建設 ・生産に要する各種の資源と, それが生み出す産出物と 
廃棄物の関係を, 出来る限り循環可能な「閉じたシステ ム」として全体を捉えることである. そして, 我々技術 者の使命亡は, このような循環の中で, 環境負荷が低減 され，資源が有効利用されて行くような技術を開発する ことであろう.このようなアプローチにより, 従来は廃 裹されていた材料を，全く異なった局面への活用を図る と言った発想も生まれてくる.

本論文で我々は，このような考え方を社会基盤構造物 の設計法に適用しようとしている，従来社会基盤施設の 設計は, 経済性と安全性と言う2つのトレードオフ関係 にある評価尺度を用いて行われてきた. 一般的には, 安 全性を安全率で表した制約条件とし，この上で経済性が 最適化するように構造物は設計されてきた. 信頼性設計 法は, 構造物の安全性を破壊確率として評価し, 構造物 が破壊したときの費用と破壊確率の関数である期待破壊 費用と, 直接の建設費の和である, 総建設費用を最小化 するような設計代替案を選ぶという構造を持っている. これは，経済性の制約上，我々は無限に安全な構造物を 建設することは出来ないと言う現実を反映しているの.

このような従来からの設計法の評価尺度に, 経済性, 安全性の他に, 環境負荷を加えたときの設計法の定式化 がどの様なものとなるべきかと言うのが，この研究の最 初の着眼点である.これは先に述へた，「閉じたシステ ム」として社会基盤施設の設計問題を定式化しょうとい うところに，狙いがある.

本研究では, エネルギー使用量の指標として, 発生す る二酸化炭素量を用いる. 二酸化炭素発生量を指標とし た理由は，これがエネルギー（特に化石燃料起源のエネ ルギー）使用量と密接に結びついていることにもよるが, 地球温暖化など環境問題に直結した指標であることも一 つの理由である.

ところで，酒井と漆崎7，外岡ら8)の研究によれば，わ が国の土木・建築を含む社会基盤施設の建設と維持管理 より発生する二酸化炭素の, 日本全体での発生量に対す る割合は，約 $1 / 3$ (炭素換算で約 3 億トン) であると言 う結果も出ている. 途方もない難題である地球規模の環 境問題からすれば，局所的なことではあるかもしれない が，上記の意味でエネルギー使用量之環境負荷を低減さ せる社会基盤施設の設計方法を考察することは, 環境負 荷を低減させるサブシステムの一つとして重要な課題で あると考える.

なお本研究と類似のアプローチとして最近注目を集め ているものにLCA（Life Cycle Assessment）がある. L C A は，環境にやさいし商品 (Environmental Conscious Product）の開発のため, 商品の生産・消費 ・廃棄の全ライフ・サイクルの発生する環境負荷を計量
し，これを低減することを目指している（Yamamoto， 1995); Boustead, 1995 ${ }^{10)}$; Gotoh, 1995 ${ }^{11)}$ ). L C Aは 本研究と極めて近い問題意識をベースとしているが, 著 者らは少なくとも次の 2 点で異なっていると考えている：

1）LＣＡは，生産における環境負荷の低減と経済開 発の競合的な関係を意識した, 商品開発における意思決 定という意識は極めてそしい. 本研究が問題としている ような社会基盤施設の計画・設計の問題では，これは避 けて通ることの出来ない問題であり，この競合関係を考 慮した意思決定の方法が, 本研究の一つの目的である.

2）ＬＣＡは，本来大量生産可能な消耗品を主体とし た製品を対象に発展してきたため, 社会基盤施設の計画 ・設計のように，規模が大きく，一品性で，構成材料が 多様, 耐用年数の長い構造物への適用については未開発 である (Okada and Koizumi, 1995 $5^{12)}$; Ikaga and Ishifuku，1995 $\left.{ }^{13)}\right)$. 本研究ではこのような構造物の工 ネルギー使用量や環境負荷を考慮することの意味につい てもできる限り考察を加えた.

著者等は，21世紀の社会基盤施設の設計代替案の採択 には, 従来の経済性と安全性の尺度に加えて, 環境負荷 やエネルギー使用量を評価尺度として取り入れなければ ならなくなると信じている.

\section{3. 従来の設計法と新設計法}

先に2章でも述べたように，現在環境問題として登場 している問題は, 従来経済発展の前提条件として無限と 考えられていた資源や，環境容量が実は有限であり，こ のため経済発展が資源や環境容量の有限性を考慮せずに は，もはや成り立たないことを示している.

本章ではこの様な視点より, 従来からの社会資本整備 計画, 特にこの一部である社会基盤施設の設計法のあり 方を反省し，将来のあるべき姿を考察するとともに，新 設計法の具備すべき条件を考察する.

\section{（1）徉来の社会基盤旗設の計画・設計法}

現在最も一般に行われている社会資本整備計画の評価 手法の一つは，費用・便益分析である. そこでは当該代 替案の実施にともない生じる便益を消費者余剩として計 量し，また代替案の実施に伴う直接的な費用を算出し， その差である純便益が大きい代替案を実施するものであ る. 上記のような計画法を，簡単な数式を用いて書くと： 
（従来の計画法）

$$
\max B(a)=B_{T}(a)-C_{T}(a)
$$

ここに， $\mathrm{B}$ ： 純便益, $\mathrm{B}_{\mathrm{T}}$ ：プロジェクト実施 により得られる余剩的な便益, $\mathrm{C}_{\mathrm{T}}$ ：総費用，

a： 代替案.

社会基盤施設の計画法と設計法が基本的に同一もので あることに着目し，設計法が一つの意思決定問題として 定式化できることを明確な形で示したのは松尾のである. すなわち, 社会基盤施設の個々の構造物の設計では, 純 便益の最大化と適正な安全性の確保という2 2 つ指標を 考慮した意思決定問題として設計法が定式化できること を示した. ところで，構造物の設計では，その構造物の 建設により生ずる便益については，その構造的な設計に かかわらずほぼ一定であると仮定できる場合がほとんど なので, 設計法の問題は, 総費用の最小化を目的とした 意思決定問題として定式化される.

信頼性設計法では，安全性に関する不確実性を設計の 中で陽に考慮し，構造物が破壊したときに生じる期待損 失費用と，建設費用の合計である総建設費用を最小化す ることにより，設計代替案の選択を行うことを提案して いる. 換言すると，安全性を期待損失費用と言う形で建 設費用と同じ金銭夕ームの評価指標に置き換え，この合 計である総費用を用いて，意思決定を行う設計法と見る ことができる.この方法では, 経済的な制約のため無限 に安全な構造物を建設することはできないという現実を, 設計法の中に直接反映させている.この場合, 問題は次 のように定式化される：

\section{（信賴性設計法）}

$$
\min C_{T}(a)=C_{C}(a)+P_{F}(a) \cdot C_{F}
$$

ここに, $\mathrm{C}_{\mathrm{C}}$ ：建設費用， $\mathrm{P}_{\mathrm{F}}$ : 破壊確率, $\mathrm{C}_{\mathrm{F}}$ ：破壊費用であり，構造物の重要度は破壊費用 $\mathrm{C}_{\mathrm{F}}$ の增大として表される.

しかし一方でその構造物の破壊費用や破壊確率を適切 に評価することは容易ではない，また，ルーチン的に建 設される構造物でこのような評価を行うことは，実務的 にも非能率的である. そこで慣用的に用いられている安 全率を用いた設計法（部分安全率を用いる設計法や，限 界状態設計法を含む）では，安全率を満足させるという ことにおいて一定の安全性を構造物に保証している（規 格化された安全性）。これは，安全性を制約条件とした 費用最小化問題と見ることができる.すなわち：

\section{（安全車を用いた設計法）}

$$
\begin{gathered}
\min C_{C}(a) \\
\text { s.t. } \quad P_{F}(a)<P_{F}{ }^{*}
\end{gathered}
$$

ここに， $\mathrm{P}_{\mathrm{F}}^{*}$ *は，ある規格化された破壊確率であり，通 常安全率として与えられる.この設計法は, 総費用最小 化と言う観点からすると，1つの簡易化された設計法と 見ることができる.

以上からわかるように，信頼性設計法でも，安全率を 用いる設計法でも，設計法への安全性の採り入れ方が異 なるとは言え，経済的な便益を最大化しようとする点で は，総便益の最大化と言う従来からの社会基盤施設の計 画法と同じ範疇に属する考え方，さらに言えば伝統的な 経济学のパラダイムに基づく考え方によって, 定式化が 行われていることがわかる.

前章までに詳しく述へできたように，資源や環境容量 を無限と考えてきた従来の経済学のパラダイムは，すで に破䅠の兆しを示しており, 現在では新しいパラダイム が求められている. 新しいパラダイムとはどのようなも のか, またその元で社会基盤施設の計画法や設計法はど のような方を目指して行けばよいのか，それが次節の 課題である.

\section{（2）新設計法が具借すべき内容}

社会基盤施設の計画や設計は, 社会全体の経済活動の 一部であり，この意味で経済学の動向を見ておくことは 重要である. 経済学の分野でも伝統的な経済学に対する 反省に立ち, 資源や環境容量の有限性を考虑した新しい パラダイムに立った理論的な枠組みの構築が盛んに試み られている，植田・落合・北畠・寺西(1991) $)^{14)}$ は，この ような経済学の動きを，(1)物質代謝論アプローチ，(2) 環境資源論アプローチ，(3)外部不経済論アプローチ， (4)社会的費用論アプローチ, (5)経济体制論アプローチ の 5 つに類型化している.

物質代謝論アプローチは, 従来の経济学が市場経済の 分析に終始し, 物質収支 (マテリアル・バランス) の分 析をなおざりにして来たことを批判し, 議論を展開して いる. このアプローチは, 物質収支の分析, 熱力学のエ ントロピー概念を導入した物質循環の不可逆性の経済学 の導入等を通し, 経済学の根本的な再構筑を展開してい る.

環境資源論アプローチは，環境をある特殊性を持った 資源（再生産不可能など）と捉え，これを経済分析モデ ルの定式化に取り入れ，特に持続可能な資源の合理的な 管理を考えようとする立場である.このアプローチは， 規範分析的な側面が強い. 


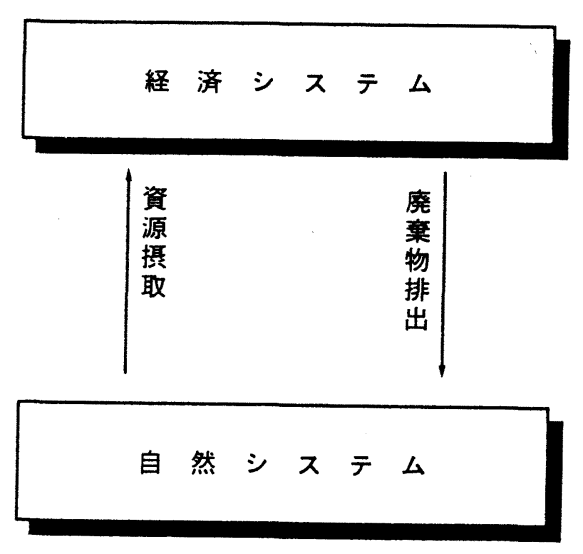

図-4 経済システムと自然システムにおける物質収支

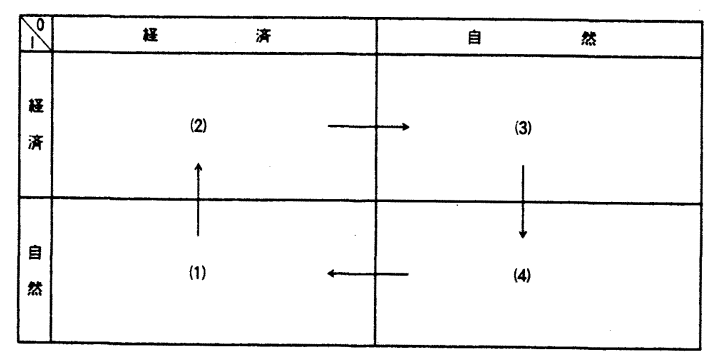

冈-5 経済システムと自然システムの連関構造

外部不経済論アプローチと, 社会的費用論アプローチ は，従来の経済学の中でも資源配分の「効率」，また所 得配分の「公正」と言った経済状態の判断の基準を展開 することを問題としてきた厚生経済学の分野にルートを 持つアプローチである. 特に前者は, 市場経済に反映さ れない外部不経済による「市場の失敗」を問題とし，こ れを何らかの手段（多くは公共的な政策手段）を用いて 市場に内部化するべきだと言う考え方を確立してきた. 一方後者は，市場に外部的な社会的費用は，経済体制上 不可避であるとする考え方を導入するなど， より政治経 済学的な志向を持っている.

最後の, 経济体制論アプローチは, 社会経済体制のあ り方が公害等の発生やそれに対する対応の仕方に違いを もたらしうるという, 政治経済学的な方法論である.
我々はこのような 5 つのアプローチの内第 1 番目の 「物質代謝論アプローチ」と，第2 番目の「環境資源論 アプローチ」が前節で展開してきたような問題に対し， 最も根本的な批判を展開していると考え，これらのアプ ローチに即して我々の考えを展開することにする. 従っ て, これらのアプローチについては, ここで少し詳しく 紹介する.

物質代謝アプローチはまず，従来経済学が分析の対象 としてきた市場システムの枠を越えて, 人間の経済活動 之, 資源や廃棄物と自然の生態系全体を含む自然システ ムとの関連に注目し，その全体での物質収支を捕え，分 析しようとした（因－4）。このアプローチが登場した 1970年代初頭には，すでに公害と言った形で環境污染 の問題が深刻化していた時代であり，従来までの経済分 析がたとえば「最終消費」として燃料, 原料, 最終製品 のような物質が，あたかもどこかに消隇してしまうよう な取り扱いをしているのに対し，これらの物質収支を明 確にし，これらを制御することを主張した。

このような物質収支の考え方と平行して，人間の営む 経済活動を, 熱力学の第 2 法則であるエントロピーの増 大として捕え，展開しようという考え方も出てきた。 す なわち，人間の経済活動は，外的な自然からさまざまな 資源として低エントロピー状態の物質を摂取し，生産， 交換，消費を通して経済活動を支え，高エントロピーの 排熱や廃棄物を外的な自然に捨てると言う不可逆過程を 通過することにより成り立ってきた。このような活動は, 外的な自然が人間の経済活動に対し無限に大きい時には 可能であろうが, 人間の経済活動が拡大し, その規模が 地球の自然システムと対置しうる大きさに達してきたと き，危機をもたらす．このような反省に立ち，現在の経 済システム, 生産システムを根源的に問い直すことが必 要であると主張した.

以上のような物質代謝論アプローチを進めて行くうえ で, 経済システムと自然システムの相互構造を捉える一 つの方法として，寺西は投入・算出分析の方法を拡張し た，目一5のような表現を提案している.

目-5の領域(2)は<経済一経済＞の領域であり，従 来からの経済循環を表し，いわゆる産業連関表により表 される.一方, 領域(1)の<自然一経済>の部分は，人 間の経済活動へ自然システムから投入される物質収支を 記述する領域である．また領域(3)の<経済一自然 >の 領域は，経済システムから自然システムへ排出されるエ ネルギーや諸物質に係わる部分である. 最後に領域(4) の<自然一自然>の領域は，自然システムにおける物質 循環を表現する領域であり，自然システムによるたとえ 
ば排出された諸物質の分解, 拡散, 固定, 蓄積過程と, それらが自然システムに与える影響などの分析が行われ る部分である.

以上見てきたように物質代謝論アプローチでは，経済 システムと自然システムの全てに関わる物質収支を解明 し，環境や資源の有限性を考虑した経済活動のあり方を 模索しようとしている. しかし，このように個々の物質 の循環のメカニズムを全体的に捉えることに多くの未解 明な点のあることは明らかであろう。これに対し，2番 目の「環境資源論アプローチ」は，環境資源と言うやや 抽象的な概念を用いて論を進めており, 前者が定量的な 分析を目指しているとすれば，後者はより規範的な分析 を目指していると言える.

北畠 ${ }^{14)}$ は環境資源論アプローチの一つの典型的なモデ ルとして，環境の自己再生能力に注目することによって， 持続可能な開発の方途を模索するため次のようなモデル を提案している. 環境の自己再生産能力は, 現在存在し ている環境の蓄積量に依存していると考え，まずこれを 環境ストック $S(t)$ と定義した．環境ストックはそれ 自身が存在することにより，環境を再生産するものであ る.

さらに現在の環境ストック $\mathrm{S}(\mathrm{t})$ の関数であるよう な環境の自己再生能力をモデルに組み込んだ。これは環 境再生産関数 $H(S)$ として定義され, 単位時間当たり の環境の自己再生能力を表す.この関数はS $\mathrm{S}$ 関して単 調増加（環境ストックが大きいほど再生産力は大きい）, 派隇的（環境ストックが大きくなるほど自己再生能力の 增加率が減少する）であると仮定する.

一方開発とは，環境ストックを投入することにより環 境以外の何らかの価值を産出することであると言える. 従ってこの場合, 開発とは環境ストックSを取り崩し, それを消費して環境以外の何らかのフローを生産する行 為と言うことになる. このフローを環境負荷（北畠では 開発フロー）と呼び，その単位時間当たりの量を 2

（t）で表すことにしょう.

以上の準備の下で環境ストックの収支を考えると，単 位時間当たり再生産される環境ストック量から, 開発に より単位時間に取り崩される環境負荷を差し引いたもの が, 環境ストックの変化率であるから, 各時間ステップ において次式が成り立つ:

$$
\begin{gathered}
\left.\frac{d S(\tau)}{d \tau}\right|_{\tau=t}=H(S(t))-z(t) \\
(t=0,1, \ldots, T)
\end{gathered}
$$

北畠(1991)はこの方程式を環境ストックの蓄積方程式 と呼んだ.この方程式の初期条件としては, 現在の環境
ストックの量を与えればよい.

一方, 北畠は開発効用関数を仮定し，開発により得ら れる効用を計量している. 結局のところこのような効用 を計量できる実際的な指標は純便益であると考えられる から，環境負荷 $z （ \mathrm{t})$ により生み出される第 $\mathrm{t}$ 期目の 純便益を $B(z(t))$ と置く．経済学ではごく一般的 な仮定である，Bの単調増加性や，派隇性を仮定する.

以上の準備の下で持続可能な発展とはどのように定式 化されるであろうか，それは，次のように表される：

$$
\begin{gathered}
\max \sum_{t=0}^{\infty} B(Z(t))(1+r)^{-t} \\
\text { s.t. }\left.\frac{d S(\tau)}{d \tau}\right|_{\tau=t}=H(S(t))-z(t) \\
(t=0,1, \ldots \infty)
\end{gathered}
$$

ここに, $\mathrm{r}$ : 社会的割引率で与件として与える.

すなわち長期的な純便益の総計を，環境ストックの蓄 積方程式の制約の下で最大化するような開発行為を選択 するのである. このような定式化をしなければ, 開発主 体は環境ストックに関する制約を無視し，短期的な視野 に立ち，時間ステップごとに便益を最大化するような開 発行為 $(B(z(t))=0)$ を繰り返し, 開発フローの拡 大が環境ストックの枯渴をもたらし, 結局は開発自体が 不可能になるような事態に突入してしまう。それが, 資 源や環境容量を無限と仮定した, 従来の経済学のパラダ イムでの開発の結果である.

北畠は，このような問題設定の基で，この問題の定常 点 $(\mathrm{d} \mathrm{S} / \mathrm{d} \mathrm{t}=0)$ に到達したとき, 環境ストックは その限界再生産性が社会的割引率と等しくなる点で均衡 する $\left(\mathrm{H}\left(\mathrm{S}_{0}\right)=\mathrm{r}\right)$ ，またこのときの環境ストック 量 $\left(S_{0}\right)$ に対応したシャドープライスにより開発税を 課すことにより，持続可能な開発が半永久的に可能であ ること等を見いだしている．また，現時点からこのよう な定常点に収束して行くための開発税政策についても, 議論している.

この「環境資源論アプローチ」は，環境ストックの具 体的な姿が明確でない，またこれに付随して実際の環境 再生産関数 $\mathrm{H}$ を决定する方法が現在のところない，環境 負荷の分配の問題（南北問題）が含まれていない，社会 的割引率を与件としている等多くの単純化はあるものの, 環境ストックの蓄積方程式を定義することを通じて，環 境がそれ自身の有限性に基づいて経済活動に課してくる 制約条件を定式化に取り入れることにより，パラダイム の転換が表現されているところに意義がある．また，資 源の問題を考えるとき，長期的な視野に立った便益や， 環境負荷の考虑が重要であることを示している.いずれ 
にせよ、このアプローチは，環境経済学の規範分析の道 具として発展して行くと考えられ，実際の定量的な分析 に使用することは当分考元られない。

以上の考察より, 社会基盤施設の新しい計画法や設計 法が具備すべき内容として，以下のような点を上げるこ とができる.

1）純粋に経斎的なメカニズムとは異なった，資源や 環境容量の有限性から課せられる制約を定式化の中に取 り込む必要がある.

2）長期間にわたる視野が評価に当たり重要である. すなわち，少なくともプロジェクトのライフサイクル （建設, 維持管理, 破棄) 全体での経済効果と環境負荷 の評価を行う必要がある.

3）上記の制約の基で，経济的な純便益の最大化を行 うことが，人口の増大に対し一定以上の福祉を保証して 行くような経済開発を可能にして行く上で必要である.

\section{4. 新設計法の桂念と定式化}

\section{(1) 锐}

本章では，エネルギー使用量を考慮した社会基盤施設 の新しい設計法を提案する．まず前章までの議論を踏ま え，資源や環境の制約を考慮した新しいパラダイムに立 つ経済システムと自然システムを同時に考慮したモデル を説明する(4.(2)a)). 一般的なモデルは非線形で極めて 複雑なモデルとなるが，この経済システムの部分を線形 化（あるいは線形であると仮定した）モテルは，産業連 関表となり，これを用いることにより自然システムから 経済システムへの資源の入力や, 経済システムから自然 システムへの廃棄物の出力をある程度定量的に捉えるこ とが出来る可能性があることを示す(4.(2)b)). 自然シス テム内の物質収支の問題は極めて複雑であり, 現在これ を完全に記述できるモデルは存在しないため，ここでは 前章で紹介した環境ストックの蓄積方程式を修正したも ので説明する.

また自然システム内の物質収支の複雑さのため, 上記 のモデルで全ての資源や廃棄物の収支を計算することは 現時点では出来ない，そこで本研究では，これらを総合 的に計量する指標として, 経済システムから自然システ ムに排出される二酸化炭素量を選んだ。 4.(2)c)では, こ の指標を選択した理由及び定量的な排出量の計算方法に ついて述へる.

4.(3)は本論文の主要部分であり，4.(2)で説明したモ デルに基づき，新しい社会基盤施設の計画や設計手法を 定式化する(4.(3)a)). 新設計法は, 経済システムと自然
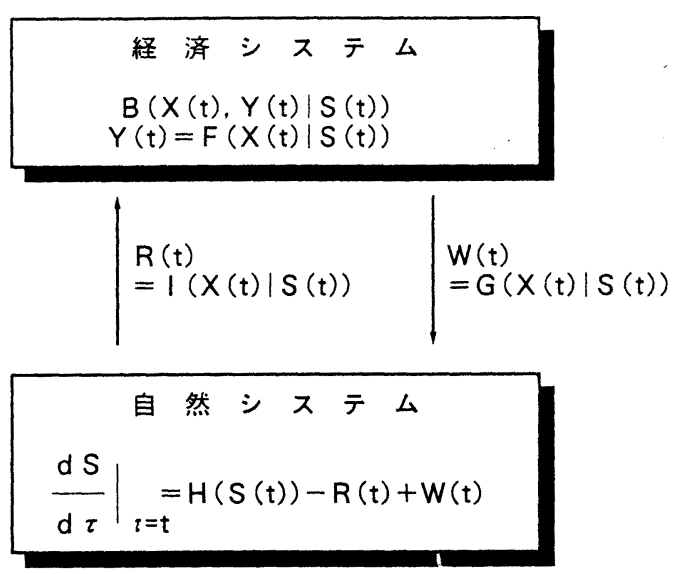

凶-6 経済一自然システムの基本モデル

システムのメカニズムを制約とした上での純便益を最大 とする意思決定問題として定式化される. 本論文では特 に純便益の算定に当たり, 総便益を考慮する必要がある 問題を「計画問題」，総便益が意思決定の結果に依らず 一定と仮定でき，従って費用最小化に目的関数が帰着す る問題を「設計問題」と定義している.

定式化された設計法では, 自然システムに対する二酸 化炭素の排出量の許容値を算定することが, 自然システ ムの複雑さのため現時点では困難である. 4.(3) b)では, この点を暫定的に回避し，環境負荷を設計法に取り込ん で行く当面の指標として carbon serviceability (C S) なる概念を導入することを提案する.

\section{（2）経洛一自然システムの基本モデルとネルギー使 用量の計量}

a) 一般モテル

目一6に本研究で提案する経済一自然システムに関す るモデルを示した，まず，経済システムにおける各産業 部門の生産量を表すべクトルを $\mathrm{X}(\mathrm{t})$ とし，この内最終需 要べクトルを $\mathrm{Y}(\mathrm{t})$ とする. このとき, 産業連関方程式と して次式が成り立つ：

$$
Y(t)=F(X(t) \mid S(t))
$$

ここに， $\mathrm{S}(\mathrm{t})$ は自然システムの中のいろいろな物質の蓄 積量を表すべクトルであり， S は総じて経済活動の環境 に影響を与える. また， $\mathrm{t}$ はこれらが第 $\mathrm{t}$ 期間のもので あることを示す.

一方, 式(6)のような経済活動により生み出される全 体の純便益（効用と言ってもよい）は, 次の関数により 計量されるとする : 
投資は，この便益を增大させるように行われると考えら れる。

経済システムは，その活動のため自然システムより生 産量 $\mathrm{X}(\mathrm{t})$ に応じた資源べクトル $\mathrm{R}(\mathrm{t})$ を摂取し，また廃棄 物べクトルW $(\mathrm{t})$ を排出している.これらは生産量 $\mathrm{X}(\mathrm{t})$ の 関数と考えられるから，それぞれ次のように表される：

$$
\begin{gathered}
R(t)=I(X(t) \mid S(t)) \\
W(t)=G(X(t) \mid S(t))
\end{gathered}
$$

これらが環境ストック量ベクトル $\mathrm{S}(\mathrm{t})$ で条件付けられる のは自然であろう。ここに，式(8)を資源負荷方程式， 式(9)を廃棄物負荷方程式と呼ぶことにする.

自然システムは, $\mathrm{R}(\mathrm{t})$ とW(t)をそれぞれ出力と入力と する極めて複雑な，物質収支システムである．これを記 述することは困難であるが，ここでは前章で紹介した 「環境資源論アプローチ」の考え方を借り，これを環境 ストックの蓄積方程式の形で与えることにする :

$$
\left.\frac{d S}{d \tau}\right|_{\tau=t}=H(S(t))-R(t)+W(t)
$$

ここに，H( $\mathrm{S}(\mathrm{t}))$ は環境の自己再生能力を表すべクト ル関数であり；物質の蓄積量べクトル $\mathrm{S}(\mathrm{t})$ の関数（すな わち多くの環境ストックが複雑な相互作用により自己再 生産を行っている）であると考えられる. なお，式(10) は物質により異なった形をしていることが容易に想像さ

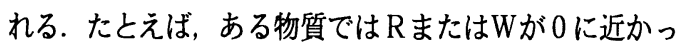
たり，また自己再生能力がほとんどない物質も存在する と思われる.この方程式は，自然システムに関する我々 の知識が極めて不十分であるため, 多くの未知の部分を 含んでいるが，資源や環境の有限性をモデルに取り込む と言う，本研究の目的のためには，有用な道具であると 考えられる.

以上の様に経済一自然システムを記述することにより， 経済システムばかりでなく，それに伴う資源や環境の自 然システムに対する負荷を，おおよそモテル化できたと 思われる.

\section{b ) 缐形化モデル}

冈ー6に示した一般モデルは，あまりにも抽象的であ ると感じられる読者も多いと思われる. そこで，これを もう少し具体的にし，また物質の収支の計量を可能にす るため，このモデルを線形化してみることにする.
非線形方程式を線形化するもっとも一般的な方法は， テーラー展開の第一項をとる方法である. 式(6)にこの 方法を適用すると：

$$
\delta Y(t)=\left.\frac{\partial F}{\partial X}\right|_{X=X(t)} \delta X(t)
$$

これは，産業連関方程式を，第 $\mathrm{t}$ 期の生産量 $\mathrm{X}(\mathrm{t})$ と環境 ストック量 $\mathrm{S}(\mathrm{t})$ でXについてテイラー展開したときの, 最終需要增分 $\delta \mathrm{Y}(\mathrm{t})$ と総生産增分 $\delta \mathrm{X}(\mathrm{t})$ の関係を示した ものである.このとき $\mathrm{F}$ が，一般の非線形関数であれば, 式(11)は $\mathrm{X}(\mathrm{t}), \mathrm{S}(\mathrm{t})$ における接線勾配となるが，もし $\mathrm{F}$ がもともと線形関数であったと仮定すると，これは通常 の産業連関分析の単位行列 $I_{n}$ から投入係数行列 $A(t)$ を 差し引いた值に一致する :

$$
\delta Y(t)=\left(I_{n}-A(t)\right) \delta X(t)
$$

式(7)は, 周知のように総生産量増分 $\delta \mathrm{X}(\mathrm{t})$ は, 最終需 要增分 $\delta \mathrm{Y}(\mathrm{t})$ と中間需要増分 $\mathrm{A}(\mathrm{t}) \cdot \delta \mathrm{X}(\mathrm{t})$ の和に一致す ることを表している :

$$
\delta Y(t)+A(t) \delta X(t)=\delta X(t)
$$

なお， $\mathrm{A} か ゙ \mathrm{t}$ の関数となっているのは，これがテー ラー展開による近似であり, 時間とともにX $(\mathrm{t})$ や $\mathrm{S}(\mathrm{t})$ が 変化すれば $\mathrm{A}$ も変化することを示している.

産業連関分析は，Leontiefにより既に1930年代後半に 考案され，その後発展してきた国民経済のフロ一面の解 析を行う枠組みである15). 単純化されているとは言え, 一般均衡を簡単な枠組みで記述しているため, 多くの応 用面を持っている. 土木計画学の分野では, プロジェク トの実施に伴う投資効果の予測や，施設の立地に伴う産 業構造の変化の予測にこの方法が用いられることがある.

式(12)を用いて, 最終需要量增分よりレオンチェフ逆 行列を介して, 総生産量増分を求めることが出来る：

$$
\delta X(t)=\left(I_{n}-A\right)^{-1} \delta Y(t)
$$

次に式(8)と，式(9)を線形化する：

$$
\delta R(t)=\left.\frac{\partial I}{\partial X}\right|_{X=X(t)} \delta X(t)
$$




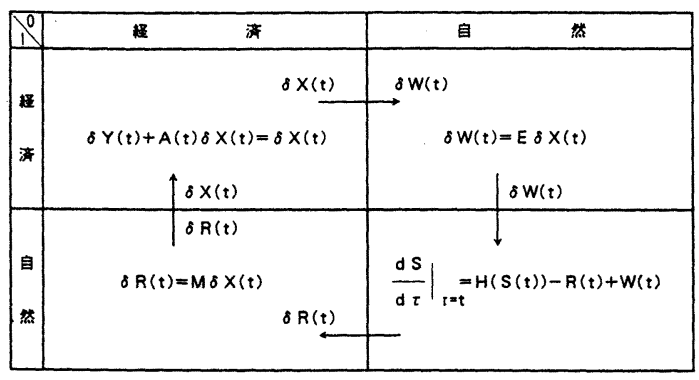

园-7 経済一自然システムの線形化モデル

$$
\delta W(t)=\left.\frac{\partial G}{\partial X}\right|_{X=X(t)} \delta X_{t}
$$

式(15)の係数行列は，生産量增分 $\delta \mathrm{X}(\mathrm{t})$ が発生すること による，資源摂取量增分 $\delta \mathrm{R}(\mathrm{t})$ を計算する行列である. これは，各生産部門で消費される原材料の構成を調査す れば求めることの出来る值である. この係数行列を，摂 取係数行列 $\mathrm{M}$ と置く.

一方式(16)の係数行列は，生産量增分 $\delta \mathrm{X}(\mathrm{t})$ が発生す ることによる, 廃棄物排出量増分 $\delta \mathrm{W}(\mathrm{t})$ を計算する行列 である.これは, 各生産部門で排出される廃棄物の構成 を調査すれば求めることの出来る值である. 事実本研究 でも二酸化炭素の排出量をこの係数を求めることにより， 計算する. この係数行列を, 排出係数行列 $\mathrm{E}$ と置く. 以 上の結果より, 式(15)と(16)は, 次のようになる：

$$
\begin{aligned}
& \delta R(t)=M \delta X(t) \\
& \delta W(t)=E \delta X(t)
\end{aligned}
$$

もちろん，式(17)と(18)をすへての物質について求める ことは不可能である. 後述するように, 本研究では経済 システムから排出される二酸化炭素量を計量することに より，これらの式で表される物質循環のおおまかな全体 像を捉えることとした。

環境ストックの蓄積方程式（式(10)）については，こ こでは線形化を行わない.

以上の結果を踏まえて，图一6に示した物質循環の関 係を行列形式で書き直したのが园一7である.

\section{c）エネルギー使用量の指標之計量方法}

本節では，この研究で用いるエネルギー使用量の指標 の選択と, その計量方法について述へる. 結論から先に

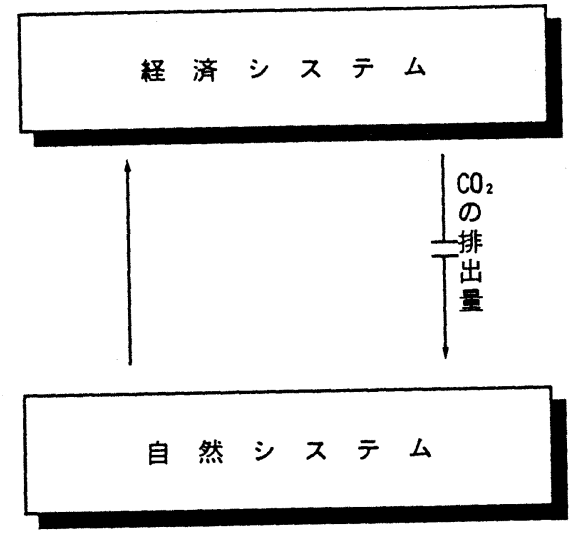

区-8 本研究における物質収支のとらえ方

述べれば, 本研究では二酸化炭素発生量をこの指標とし て用いた. 二酸化炭素排出量を指標に選んだ理由, 及び その発生原単位の推定法について述べるが，本節の目 的である.

\section{1) エネルギー使用量の指標}

既に述へてきているように，本研究の目的は，資源や 環境容量が有限であると言うことを認めた上で，なお必 要な経済発展を持続的に可能にするような，新しいパラ ダイムにおける社会基盤施設の設計法について提案する ことである.この目標を達成するためどのような指標を 用いて，エネルギー使用量や環境負荷を定量的に計量す るかということが問題である.

提取資源や排出廃棄物を細部に渡って考えて行くと化 石燃料, 鉱物資源, 稀少金属, 温室効果ガス, 森林, 各 生物種, 各種廃棄物量, 微量污染物質, 土垬等無数に存 在し，これらすへてを考慮しモデル化することは不可能 である.これは，图一7に示した物質収支の全ての項目 を考慮することに相当する．そこで，本研究ではこれら の負荷を大まかに捕らえる指標として，各経済活動によ り発生する二酸化炭素量を用いることにした。これは， 目一6の経済システムから自然システムへ排出される物 質の代表指標として二酸化炭素を選んだことに相当する （因-8）．その理由は以下の通りである：

1) 資源の有限性が論ぜられるとき，その当面の中心 的な課題は石油，石炭，天然ガス等のいわゆる化石燃料 の可採年数である. 二酸化炭素の発生量は，これら化石 燃料の燃焼と直結しており, 経济活動のエネルギ一使用 量を計量する上で，もっともふさわしい指標の 1 つであ ると考えられる。 


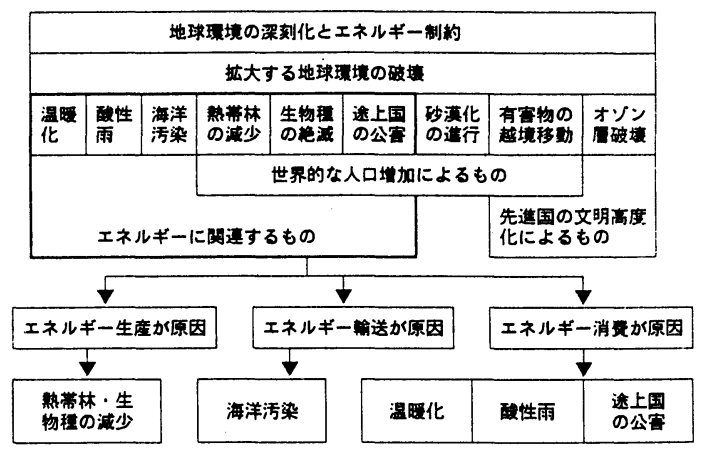

龱-9 地球環境問題とエネルギーの関係

2) 現在地球環境問題として議論されている問題の中 の多くは，目一-9に示されるように，温暖化，酸性雨， 途上国の公害等, 化石エネルギー使用量と直接結びつい ているものが多い，従って，化石然料の使用量之直接結 びついている二酸化炭素発生量は, 適当な指標である.

3)特に温暖化は, 二酸化炭素発生量と直結していると 考えられる. 文献によっては，資源枯渇より先に，地球 温暖化の影響の方が人類の生存にとりクリティカルとな り，人類は資源の枯渴を待つまでもなく，温暖化による 海面上昇や気候の変動等で決定的な危機を向かえると予 測するものもある.

\section{2) 二酸化炭素発生原単位の推定}

ある財 1 単位を使用したときに発生する二酸化炭素量 を，二酸化炭素発生原単位と言う. 原単位の推定は，そ の財の生産にさかのぼり，その工程で発生したすへての 二酸化炭素を累計する必要がある. 本研究での原単位の 算出は，産業連関表を用いる方法で得られたものを利用 する.

わが国では，1960年以来5年毎に政府より産業連関表 が公表されており，わが国の経済の実態を把握するため の貴重な資料として活用されている.

産業連関表は，種々の産業間の財の入出関係を定量的 に記述したものであるので，たとえば本研究で求めよう としている二酸化炭素原単位の算出を行おうとする場合 など，ある最終財を生産するために他の財がどの様に投 入されてきたかを求めることができる.

産業連関表を用いて $\mathrm{C} \mathrm{O}_{2}$ の排出原単位を算出方法の 基本的な考え方は，以下の通りである.

まず， $\mathrm{CO}_{2}$ の排出につながる燃料等のエネルギー材 に着目し，各材を生産するときの，これらエネルギー材 の燃料に使用される割合, それぞれのエネルギー材の高
発熱量, 熱量当りの $\mathrm{C} \mathrm{O}_{2}$ 発生係数等を調へ, これより 排出係数べクトル $\mathbf{e}_{\mathrm{j}}$ を求める.この量は, 第 $\mathrm{j}$ 材につ いてベクトル $\mathbf{e}_{\mathbf{j}}$ として表され，エネルギー材以外の材 についての係数は 0 である.このとき参考とする資料は, 石油等消費構造統計，鉄鋼統計，ガス事業統計等である。 例えば外岡 $(1994)^{(8)}$ は, 各部門材の $\mathbf{e}_{\mathbf{j}}$ を, 次のように求 めている :

$\mathbf{e}_{\mathbf{j}}=$ (第 $\mathrm{i}$ エネルギー材の 1 単位の重量 $; \mathrm{t}$ )

-（第 $\mathrm{j}$ 部門材の生産に投入される第 $\mathrm{i}$ エネルギー材の 内，燃料用に使用されたエネルギー材の割合）

-（第 $\mathrm{i}$ エネルギー材の高発熱量; G c a $1 / \mathrm{t}$ )

- ( C O2排出係数 ; $\mathrm{t} / \mathrm{G} \mathrm{c}$ a 1$)$

一方, 第 $\mathrm{j}$ 材を一単位生産するときの各材の投入量べ クトル $\mathbf{x}_{\mathrm{j}}$ は，産業連関分析を利用し，式(14)を用いるこ。 とにより次のように計算出来る：

$$
x_{j}=[I-A]^{-1} f_{j}
$$

ここに， $\mathbf{f}_{\mathbf{j}}$ は，第 $\mathrm{j}$ 番目の要素が 1 , その他は 0 の綐 ベクトルである.

さらに, $\mathrm{C} \mathrm{O}_{2}$ の発生を考える場合, 最終財が燃料で ある場合，最終的にこれも燃焼され， $\mathrm{CO}_{2}$ が発生する から，これを最終消費による排出としてC ${ }_{\mathrm{j}}^{\mathrm{j}}$ で表す.

以上の準備のもとで，第 $\mathrm{j}$ 財の $\mathrm{C} \mathrm{O}_{2}$ 発生原単位を求 める :

$$
C^{B}{ }_{j}=e_{j} \cdot x_{j}+C^{e}{ }_{j}=e_{j}[I-A]^{-1} f_{j}+C^{e}{ }_{j}
$$

\section{3 ) 原単位の算出結果}

前述したように, 本研究では外岡ら息の行った $\mathrm{C} \mathrm{O} 2$ 原 単位の算出方法を中心に述へ，算出結果については他の 研究の結果も従記するものとする.

外岡は, 1985 年の産業連関表基本表（529行 x 408 列）より正方化した406行 x 406列の投入産出表をつく り，内建設部門11列について建設部門産業連関表の66 列（中間計を除くと31列） x 213列（基本表529行のう ち建設部門への直接投入のあった行のみ抽出）を用いて 細分化し，建設部門を取り込んだ441行 x 441列の正方 投入産出表を作成した。この正方441部門表を用いて $(\mathrm{I}-\mathrm{A})^{-1}$ 型と $(\mathrm{I}-(\mathrm{I}-\mathrm{A}))^{-1}$ 型の逆行列を作 成し，これより式(21)を用いて，各財の誘発 C O 2 排出 量を推定している.

外岡の推計方法が, 他の推計と比較して優れていると 
表-3 主な建設材料の二酸化炭素発生量原単位 ${ }^{16)}$

（原単位はkg-c，すなわち炭素発生量で与えられている）

\begin{tabular}{|c|c|c|c|c|c|}
\hline 引用資料 & 果 位 & 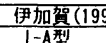 & 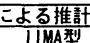 & $\begin{array}{l}\text { 酒开ら(1992) } \\
\text { による推致 }\end{array}$ & $\begin{array}{l}\text { 土木研究所に } \\
\text { 推計 }\end{array}$ \\
\hline 鉄鋼（粗铜） & $\mathrm{kg} / \mathrm{t}$ & 352 & 305 & 515 & \\
\hline 普通鋼型鋼 & $\mathrm{kg} / \mathrm{t}$ & 349 & 305 & & $360 \sim 2630$ \\
\hline セメント & $\mathrm{kg} / \mathrm{t}$ & 220 & 216 & 81 & 85. 8 125 \\
\hline 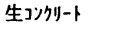 & $\mathrm{kg} / \mathrm{m}^{3}$ & 65.6 & 63 & & $26.4 \sim 49.0$ \\
\hline 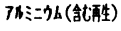 & $\mathrm{kg} / \mathrm{t}$ & 900 & 708 & 616 & \\
\hline 製材 & $\mathrm{kg} / \mathrm{m}^{3}$ & 28.5 & 19.4 & $7.8(\mathrm{~kg} / \mathrm{t})$ & $1.7 \sim 34.9$ \\
\hline 砂利・探石 & $\mathrm{kg} / \mathrm{t}$ & 2.2 & 2 & & \\
\hline 碚石 & $\mathrm{kg} / \mathrm{t}$ & 2.8 & 2.5 & 0.3 & \\
\hline 奵油 & $\mathrm{kg} / \mathrm{G}$ 加 & 83.5 & 78.7 & & 86.3 \\
\hline 轻油 & $\mathrm{kg} / \mathrm{G}$ 和 & 92.3 & 85.7 & & 86.9 \\
\hline A重油 & $\mathrm{kg} / \mathrm{G}$ 㹱 & 84.9 & 80.5 & & 87.8 \\
\hline B - C 重油 & $\mathrm{kg} / \mathrm{G} \eta$ & 89.8 & 86 & & 87.8 \\
\hline
\end{tabular}

思われる理由の一つは, 各燃料より発生する $\mathrm{C} \mathrm{O}_{2}$ 排出 量の推計を, 相当丁寧に行っている点である. すなわち, $\mathrm{C} \mathrm{O}_{2}$ の排出があるのは, 燃料製品等, 特定の投入に限 られるが，投入金額から求めるより，投入量から求める 方が正確である．従って，物量表がある場合はこれを用 い，物量表がない場合は，投入量が得られる他の統計を 活用し，石油等消費構造統計，電気事業統計，鉄鋼統計， ガス事業統計，エネルギー生産需要統計等から，詳細な 燃料種類別の投入量を推計し, 補足的な物量表を独自に 作成している.

さらに投入された燃料製品の燃料として燃焼される割 合, すなわち「燃焼比率」を石油等消費構造統計から求 め, また各燃料製品の「高発熱量原単位」や「 $\mathrm{CO}_{2}$ 排 出係数」に関しても, 諸機関からの推萀値を慎重に吟味 するなど，多くの細かい配慮を払っている.

また，特に鉄鋼製品については，製造が高炉転炬によ る場合と，電炉による場合では $\mathrm{C} \mathrm{O}_{2}$ 発生量に相当な差 があることを考慮し，各鉄鋼製品毎に高炉転炉綱と電炉 綱の混合割合を鉄鋼統計より工程別に推計し，鉄鋼製品 毎に誘発C O 2排出量を補正している.これにより，鉄 骨と鉄筋の誘発排出水準の違い等も評価できる.

表一3に外岡の行った推計結果を，伊香賀が二次加工 した値を，当面我々の関心のある項目につき整理した ${ }^{16)}$. また, このほかに酒井らの推計)と，建設省土木研究所 の行った推計結果 ${ }^{17}$ についても比較のため示した. $\mathrm{CO}_{2}$ 誘発量が多いのは, 鉄鋼製品, セメント製品が大 きい.なお，表 3 に記されているのは，炭素発生量 $(\mathrm{kg}-$ c)である.

\section{（3）新設計法}

\section{a ) 基本定式化}

社会基盤施設の計画や設計では，与えられたいくつか の代替案の中から便益の最大となるものを選択すると言 う意思決定が問題となる. 代替案を $\mathrm{a}_{\mathrm{i}}$ と表すと，これは 経済システムの中の一組の最終需要量増分の組み合わせ として表現されるので, 次のように書くことが出来るで あろう:

$$
a_{i}: \delta Y\left(t \mid a_{i}\right) \quad(i=1, \ldots, N)
$$

このとき,この代替案 $\mathrm{a}_{\mathrm{i}}$ の実施により得られる各生産部 門の生産量の増加は式(6)より:

$$
\delta X\left(t \mid a_{i}, S(t)\right)=\left.\frac{\partial F^{-1}(X, Y \mid S(t))}{\partial Y}\right|_{Y=Y(t), X=X(t)} \delta Y\left(t \mid a_{i}\right)
$$

このときの便益は, 式(7)により計量され：

$$
\delta B\left(t \mid a_{i}\right)=\left.\frac{\partial B}{\partial X}\right|_{X=X(t)} \delta X\left(t \mid a_{i}\right)
$$

便益の計量方法には，代替案実施による最終需要増分の 波及効果による付加価値の増加を計算したり，また費用 便益分析法を用い消費者余剩を計算する等いくつかの方 法があり，ここではその方法は特定しない。

一方, 代替案の実施により発生する資源摄取増分之廃 棄物排出量增分は, 次の様に計算される：

$$
\begin{aligned}
& \delta R\left(t \mid a_{i}\right)=\left.\frac{\partial I}{\partial X}\right|_{X=X(t)} \delta X\left(t \mid a_{i}\right) \\
& \delta W\left(t \mid a_{i}\right)=\left.\frac{\partial G}{\partial X}\right|_{X=X(t)} \delta X\left(t \mid a_{i}\right)
\end{aligned}
$$

このような資源摄取量や廃棄物排出量の増加は, 最終的 に環境ストックの蓄積方程式に次のような影響を与える：

$$
\begin{gathered}
\left.\frac{d S}{d \tau}\right|_{\tau=t}=H(S(t)) \\
-R(t)-\delta R\left(t \mid a_{i}\right)+W(t)+\delta W\left(t \mid a_{i}\right)
\end{gathered}
$$


以上のような準備の基で，計画法や設計法の一般的な 定式化は，次のように書くことが出来るであろう：

$$
\begin{gathered}
\max \sum_{t=0}^{T} \delta B\left(t \mid a_{i}, S(t)\right)(1+r)^{-t} \\
=\sum_{t=0}^{T}\left\{\delta B_{T}\left(t \mid a_{i}, S(t)\right)-\delta C_{T}\left(t \mid a_{i}, S(t)\right)\right\}(1+r)^{-t} \\
\text { s.t. }\left.\frac{d S(\tau)}{d \tau}\right|_{\tau=t}=H(S(t)) \\
-R(t)-\delta R\left(t \mid a_{i}\right)+W(t)+\delta W\left(t \mid a_{i}\right) \\
(t=0,1, \ldots T)
\end{gathered}
$$

ここに $\delta \mathrm{B}_{\mathrm{T}}$ は, 当該代替案の実施により発生する総 便益を， $\delta \mathrm{C}_{\mathrm{T}}$ はその総費用を表しており， $\mathrm{T}$ は，当該 社会基盤施設の供用期間である.

式(28)では，便益や費用が環境ストック $\mathrm{S}(\mathrm{t})$ の関数と なっており，また $\mathrm{S}(\mathrm{t})$ は代替案の実施により発生する環 境負荷（資源摂取量と，廃棄物排出量を合わせて環境負 荷と呼ぶ）の影響を受けて変化し，これが制約として考 虑されていることに注意を要する。

先にも述へたように，伝統的に土木工学では，便益の 計量を主に考慮する問題を計画問題，その意思決定に よっては便益には大きな変化のないような問題を設計問 題と分類してきたように思われる．そこで本研究では, このような事実を考慮し，設計法を次のように定義する：

「社会基盤施設計画の意思決定において，当該プロ ジェクトの便益がその決定により影響を受けない意思決 定問題」

上記のように設計法を定義すれば，式(28)の $\delta \mathrm{B}_{\mathrm{T}}$ は 一定となり，設計問題は式(28)に基づき費用最小化問題 として, 次のように定式化される：

$$
\begin{gathered}
\min \sum_{t=0}^{T} C_{T}\left(t \mid a_{i}, S(t)\right)(1+r)^{-t} \\
\text { s.t. }\left.\frac{d S(\tau)}{d \tau}\right|_{\tau=t}=H(S(t)) \\
-R(t)-\delta R\left(t \mid a_{i}\right)+W(t)+\delta W\left(t \mid a_{i}\right) \\
(t=0,1, \ldots T)
\end{gathered}
$$

上の定式化で，その制約条件をなす環境ストックの蓄 積方程式について，次のことが言える：

1)現在の環境ストック量 $\mathrm{S}(\mathrm{t})$ は, 極めて大きな值であ り，ここで議論している意思決定問題とは関係なく，与 えられていると考えてよい．また許容される環境ストッ
クの変化率（左辺）も，既に与件として与えられている と仮定してよいであろう.

2)時間ステップ $\mathrm{t}$ における当該代替案の実施以外で発 生する環境負荷 $R(t) や W(t)$ は, 当該代替案の実施で発生 する環境負荷 $\delta \mathrm{R}(\mathrm{t})$ や $\delta \mathrm{W}(\mathrm{t})$ に比へ，遥かに大きく，与 件として与えられると考えられる.

3)当該代替案の実施で発生する環境負荷 $\delta \mathrm{R}(\mathrm{t})$ や $\delta \mathrm{W}$ ( $\mathrm{t})$ は，全体の持続的発展を可能にする環境負荷を上限と し，できるだけ小さい方がよい.

以上より，式(29)の制約条件は次のように書き直すこ とができる :

$$
\min \sum_{t=0}^{T} C_{T}\left(t \mid a_{i}, S(t)\right)(1+r)^{-} t
$$

s.t. $\delta W\left(t \mid a_{i}\right)-\delta R\left(t \mid a_{i}\right) \leq E^{*}(t)=$ const.

ここに,

$$
\begin{gathered}
E^{*}(t)=H(S(t))-\left.\frac{d S(\tau)}{d \tau}\right|_{\tau=t}-R(t \mid S(t))+W(t \mid S(t) . \\
(t=0,1,2, \ldots T)
\end{gathered}
$$

式(30)は，環境負荷を考慮した社会基盤施設設計法の 最も基本的な定式化であり，以下では新設計法の基本定 式化と呼ぶことにする.

本研究では，式(30)の制約条件をすへての物質につい て行うことは, 現在我々の持っている知識の範囲では全 く不可能であることを認識し，それらの代表値として二 酸化炭素の発生量をとり，これを制約するような設計代 替案の選択を考えるという立場をとる.このとき $\delta \mathrm{R}(\mathrm{t})$ は, 当該代替案を実施したときの二酸化炭素の固定量 (植林等)， $\delta \mathrm{W}(\mathrm{t})$ はその発生量, $\mathrm{H}(\mathrm{S}(\mathrm{t}))$ は自然シ ステムの二酸化炭素の固定を支配する関数であるが，こ れは二酸化炭素のストック量ばかりでなく，他の環境ス トック (例えば森林の量) の関数でもあることには注意 を要する. しかし，これら関数を設定することも現在の 我々の知識では，容易ではない，制約值 $\mathrm{E} *(\mathrm{t})$ をどのよ うに決定するかも今後の課題とならざるをえない。

\section{b) Carbon Seviceabilityと実用定式化}

1) Carbon Serviceability

本研究における環境負荷を考慮した新設計法の基本定 式化を先に，式(30)に示した．本節では，この定式化を もう少し具体的に考え，実際に意思决定を行うことがで きるような形に変形することを考える．まずはじめに， この定式化の源泉となった考え方を再考察してみたい. 
この式では，総費用が最小化されることを目的として いる.これは，さかのぼれば純便益の最大化を考えたも のであったが, 設計問題のような社会基盤施設計画全体 の中で下位の决定に属するような意思决定問題では，そ の決定の結果が総便益の評価にはほとんど影響しないと 考えられるため, 総費用の最小化という目的関数が採ら れたのであった.

ところで，総費用の内訳は，実際に建設・維持管理・ 破棄にかかる費用の他に，万一構造物が破壊したときに 発生する破壊費用が，その不確実性を考慮し，期待破壊 費用と言う形で入っている.これは，経済的な制約のた め, 我々は無限に安全な構造物を作ることはできないと 言う動かしがたい現実を, 定式化したものである. 換言 すれば，構造物の安全性は，結局経済的な制約で制限さ れており，従って金銭タームで評価でされるとした定式 化である.

一方，環境負荷は環境ストックの使用に関する制約条 件亡言う形で, 定式化に導入されている.このことを反 省すると，これは経済的価值では計量することの出来な い，資源や環境容量の有限性から来る制約を考慮しなけ れば，人類の生存そのものが危険にさらされると言う， パラダイムの変化に起因し, 課せられる制約条件である 之言える.この制約は, 従来の市場均衡から決まる可変 な制約（石油価格が上がれば，開発可能な油田が増え， 供給量が増す)ではなく、環境ストックの蓄積方程式か ら来る絶対的な制約条件である.

ところで，ここで環境負荷に関する制約が絶対的な制 約条件であると記したが，この具体的な制限值 (E*) を決定することは，現時点では容易ではない，我々が， 環境ストックとその再生産関数について持っている知識 は，地球温暖化問題のように大きな注目を集めている問 題でさえも，まだ非常に大きな未知の領域を含んでいる. 従って, 当面この絶対值を決定することは, 困難である と思われる.（たとえ二酸化炭素の発生量を1990年レ ベルに押さえると言うことが全世界的に合意されたとし ても，これを基に規準值を各レベルで設定することは， かなり難しいと考えられる. しかしも，1990年の二酸 化炭素発生レベルが地球温暖化防止上, 必要かつ十分な 条件であるという保証は，現在のところ何もない）

この困難を, 当面便宜的に回避し, しかも環境負荷を 出来る限り低減させて行くために有効な指標として, 我々は「Carbon Seviceability（以下C Sと呼ぶ）」な る概念を提案する. C S は, 次のように定義される：

「当該プロジェクト, 施設, 構造物, あるいは部材が 提供する全供用期間中のサービスの総量を, それらが建
設, 供用, 廃棄の全期間に排出する全二酸化炭素量で除 した値」

すなわち，1 単位の二酸化炭素が提供するサービスの量 を， C S と呼ぶのである.

ここでまず，「サービス」と言う言葉を用いたのは, 我々はプロジェクト，施設，構造物さらにはその構成部 材の一つ一つに共通する概念を定義することを意図した からである.すなおち，プロジェクト，施設などでは サービスは, 供用期間中の純便益の総量と言う言葉で置 き換えられてよい. しかし, 構造物, さらには部材とな ると，その便益を直接計量することはできない，その 「サービス」は，ある機能を一定期間果たす，またある 荷重を一定期間支持する，と言う表現しか取れない，例 えば, 2 車線 $\mathrm{T}-25$ 荷重, スパン $30 \mathrm{~m}$ の道路橋梁を 25 年間機能させるとか, 径間 $7 \mathrm{~m}, 0.3 \mathrm{t} / \mathrm{m}^{2}$ の等分布荷 重を40年間支持する単純梁と言ったものが，「サービ ス」の具体的な内容である.

また, 特にサービスの提供を受けられる時間の長さを 問題にするのは，見てきたようにエネルギー使用量や環 境負荷の問題では, 時間が非常に重要な要因であるから である、材料開発等により, より長い期間機能を果たす 部材があれば, 結果的にそのC S は高くなる.

以上より分かるように，CS は我々が社会基盤施設か ら受けているサービスが, どの程度のエネルギー使用量 や環境負荷により支えられているかを示す指標であると 言える.これは特に我々がこの研究で問題としている構 造物の設計をエネルギー使用量や環境負荷との関係で考 えるとき，有用な指標であると考えられる．式(30)は 従って，CSを用いると，次の様に書き換えることがで きる :

$$
\begin{gathered}
\min . \sum_{t=0}^{T} C_{T}\left(t \mid a_{i}\right)(1+r)^{-t} \\
\text { s.t. } \quad \operatorname{CS}\left(a_{i}\right) \geq C S^{*}
\end{gathered}
$$

C S を導入すると次のような利点があると考えられる. 1) 同じ種類の, しかし異なる量のサービスを提供す る構造物, 部材などを, 相対的に比較するのに便利な指 標である.

2) C Sの下限值を何らかの方法で决定できれば，こ れを制約条件として費用の最小化を行うような設計代替 案の選択を行うことが出来る. たとえば，二酸化炭素排 出量を1990年レベルに安定化させると言う目標が設定 されれば,このときの標準的な構造物, や部材の C Sを 
表一４新設計法の実用定式化一覧

\begin{tabular}{|c|c|c|c|}
\hline & $\begin{array}{l}\text { C Sを制約条件として導入した } \\
\text { 設計法 } \\
\end{array}$ & $\begin{array}{l}\text { 謤境負荷の換算率を導入した } \\
\text { 設計法 }\end{array}$ & $\begin{array}{l}\text { C S の最小化を導入した } \\
\text { 設計法 }\end{array}$ \\
\hline 信頼性設計法 & $\begin{array}{l}\text { 定式化 } \mathrm{I}: \\
\quad \min . C_{c}+C_{f} \cdot P_{f} \\
\text { s.t. } C S \geq C S^{\circ}\end{array}$ & $\begin{array}{l}\text { 定式化 II : } \\
\quad \min . C_{c}+C_{f} \cdot P_{f}+\alpha_{z} \cdot z\end{array}$ & $\begin{array}{c}\text { 定式化 III : } \\
\text { min. } C_{c}+C_{f} \cdot P_{f} \\
\quad \max . C S\end{array}$ \\
\hline $\begin{array}{l}\text { 安全率を用いた } \\
\text { 設計法 }\end{array}$ & 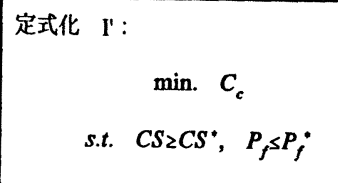 & \begin{tabular}{|l} 
定式化 $\mathrm{II}:$ : \\
min. $C_{c}+\alpha_{z} \cdot z$ \\
s.t. $P_{f} \leq P_{f}$
\end{tabular} & $\begin{array}{l}\text { 定式化 III' : } \\
\text { min. } C_{c}, \max . C S \\
\text { s.t. } P_{f} \leq P_{f}\end{array}$ \\
\hline
\end{tabular}

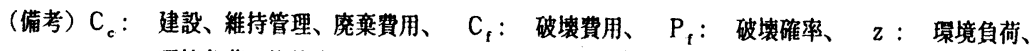

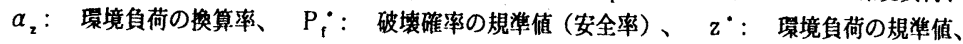

C S : carbon seviceability, $\mathrm{CS}^{\circ}$ : carbon seviceabilityの基準值

求め, 総量の減少のための低減率をこれに考虑し, 制約 条件を設定できるであろう.

3）新技術の開発による直接的な二酸化炭素発生量の 低減や，長寿命化の効果などをC S を通じ直接的に設計 に持ち込むことが可能となる.

\section{2) 実用定式化}

以上の考察の基で，可能な実用定式化は，表 4 に示す ように，次のようなものが考えられる.

\section{（定式化I：C S 制的を導入した定式化）}

式(31)の定式化通り，建設費用等の直接費用之，期待 破壊費用の合計である総建設費用を, Carbon Serviceability制約の下で，最小化する．このとき，CＳの許容 值を決定するのは必ずしも容易ではないが，現状のC S と相対的な比較を行うなどすれば必ずしも不可能ではな い. なお本研究の考察の流れでは，最も自然な定式化で ある.

\section{（定式化 I'）}

(定式化 I)とほとんど同様であるが，構造物の安全性 を，目的関数に入れず，制約条件とする.すなわち， C S と安全性に関する制約条件の基で，建設費用等の直 接費用を最小化する.

\section{（定式化II : 桭境目荷换算本を導入した定式化）}

環境負荷に換算率を掛けて金銭夕ームに変換し，これ 之総建設費用の合計という，一元化された評価関数を用 いた，制約条件のない最小化問題として定式化する.こ のとき，換算率（例えば，炭素税）をうまく調整すれば,
定式化Iで示したC S を満足するように出来る．その意 味で，定式化IとIIは，等価な定式化である．換言すると， この換算率は炭素税のようなものを考えており，この費 用を課すことにより，市場メカニズムを通じて資源摄取 量や廃棄物排出量が抑制され, 結果的にC S“が達成さ れるような換算率が選択されるべきである.

\section{（定式化 II'）}

(定式化 II) と類似しているが，安全性を目的関数に 入れず，制約条件とし，建設費用等の直接費用と，環境 負荷に換算率を掛けた值との和よりなる目的関数を最小 化する.

\section{（定式化III : 㻴境負荷最小化を導入した定式化）}

C S 制約の制限值の決定が困難であることを考虑し， 総建設費用とC Sをともに最小/大化するような，多目 的最適化問題といして定式化する. ただし，これらの 2 つの目的関数を同時に最小/大化する解が存在するとい う保証はない. 多目的計画法でこの問題を解いた場合, パレート解と呼ばれる幾つかの解を導く.これらパレー 卜解から最終的に一つの解を選択するためには, 多属性 効用関数論や階層分析法 (AH P) など, 多軸評価尺度 を一元化する方法が必要であると思われる.

\section{（定式化III）}

(定式化 III)と類似しているが，安全性を目的関数に 入れず，制約条件とした上で，建設費用等の直接費用と， C Sを同時にを最小/大化する, 制約条件付き多目的最 適化問題として, 定式化する. 
それぞれの定式化の命名からも分かるように，C Sま たは環境負荷を，(I)制約条件，(II)換算率による金銭 タームでの評侕, (III)最大化, として扱っている点がこ の 3 つの定式化の違いである. それぞれプライムのつい ている定式化では, 安全性に関する評価を目的関数から はずし，制約条件として取り扱っている点が異なってい る.

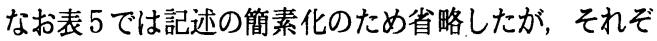
れの代替案の費用や環境負荷の算定に当たっては，プロ ジェクトライフを通して，建設，供用，廃棄の全過程で 発生する費用やC S（環境負荷）を算定し，考虑する必 要があるのは, 言うまでもないことである.

C Sの具体的な利用例は，次章の例題を参照されたい.

\section{5. 简単な例題}

\section{(1) 単媇梁の例}

まずはじめに単純梁に関する例題を示し，C S を用いることの意味を説明する.

例題 $1 \mathrm{~A}$ : この例題では，スパン7.5mの単純梁 において材料を変え，それぞれの環境負荷を計算 している（表－5）。このような場合各設計代替 案の二酸化炭素発生量を直接比較することにより, 環境負荷を比較し，また建設費用を比較すること により経済性を比較できる．この場合，木材が最 も環境負荷が少ないことが分かる.

例題 $1 \mathrm{~B}$ : 実際の計画・設計では，ある幅を 持った条件下での環境負荷の比較が必要である。 単純梁を例にとれば，実際の設計条件は特に計画 段階では例題 $1 \mathrm{~A}$ で示す「7.5mのスパン」と決め られているのではなく，「川を渡る」などの条件 の下で, 便益がスパンを変えることに応じて変化 すると想定し, 何メートルのスパンで単純梁を設 計するのが最も経済的であるか，あるいは環境負 荷が少ないかと言う視点が重要となる．このよう な場合，CSの考え方の有効性が現れる.

この例題では, $5.0 \mathrm{~m}, 7.5 \mathrm{~m}, 10.0 \mathrm{~m}$ の 3 通りの スパンに対して C S を求めた（表－ 5 及び表一

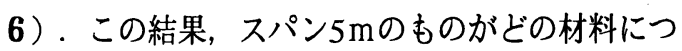
いても最大のC Sを与えたが，これは総便益がス パンと寿命の積である場合の結果であり，例えば スパンの代わりに最大曲げモーメント $\mathrm{Mmax}$ 年寿 命の積を総便益とすると，スパン $7.5 \mathrm{~m}$ 場合がど の材料においても最大の C S を与える.このよう に単位発生二酸化炭素当りの便益, すなわちC S で比較すると，木材を除けば，スパンの違いによ
表一5 例題 $1 \mathrm{~A}$ : スパン7.5mの単純梁の二酸化炭素発生量及びC S

\begin{tabular}{|c|c|c|c|c|c|c|}
\hline & 3119 & k 14 & 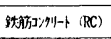 & 3 政 & アルミニウム & 满 \\
\hline - & H 㙁 & that $2,(30)$ & $\begin{array}{l}\mathrm{R}: \mathrm{SD} 295 \\
\mathrm{C}: \sigma_{:=x}=240\end{array}$ & S S 400 & - & 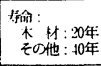 \\
\hline (2) & 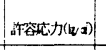 & 95 & $\begin{array}{ll}\text { R : } & 2000 \\
C & : 80 \\
\end{array}$ & 1600 & 1340 & \\
\hline (3) & 粰面 (an) & (a): & 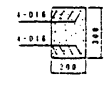 & $T_{1009}^{5}$ & T四 & \\
\hline (4) & 粕面俰数 (cam) & 3000 & - & 184 & 285 & \\
\hline (5) & 作用店加( $(\mathrm{k} / \mathrm{d})$ & 87 & $\begin{array}{l}R: 1550 \\
C:: 75\end{array}$ & 1410 & 910 & \\
\hline (4) & 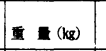 & $135\left(0.45 \mathrm{~m}^{2}\right)$ & $\begin{array}{ll}R: & 90 \\
C & 1040 \\
\end{array}$ & 160 & 57 & \\
\hline (a) & 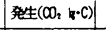 & 13 & 100 & 56 & 51 & \\
\hline (8) & 便益 (m.*n) & $\begin{array}{c}7.5 \times 20 \\
150 \\
\end{array}$ & $\begin{array}{c}7.5 \times 40 \\
300 \\
\end{array}$ & $\begin{array}{r}7.5 \times 40 \\
300 \\
\end{array}$ & $\begin{array}{l}7.5 \times 40 \\
300 \\
\end{array}$ & \\
\hline (ब) & C.s. $(1 / 0)$ & 12 & 3 & 5.5 & 6 & \\
\hline (1) & 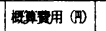 & 43.500 & 21,200 & 9,600 & 68,400 & \\
\hline
\end{tabular}

表-6 a 例題 $1 \mathrm{~B}$ ：スパン $5.0 \mathrm{~m}$ 単純梁の二酸化炭素発生量及びC

\begin{tabular}{|c|c|c|c|c|c|c|}
\hline & 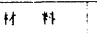 & 木 仏 & $850253,9 y-1$ (RC) & 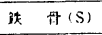 & アルミニウム & 幣 \\
\hline il & 忉琠 & 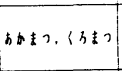 & $\begin{array}{l}\mathrm{R}: \mathrm{SD} 295 \\
\mathrm{C}: \sigma_{\mathrm{c} \times}=240\end{array}$ & $S$ S 400 & - & 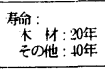 \\
\hline 2 & 許容蛇力 $(\mathrm{w} / \mathrm{a})$ & 95 & $\begin{array}{l}\mathrm{R}: 2000 \\
\mathrm{C}: \quad 80 \\
\end{array}$ & 1600 & 1340 & \\
\hline 3) & 頪 (m) & 단 & 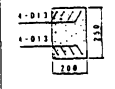 & T掯 & IIS & \\
\hline (4) & 糆面䋆数 (cmi) & 1333 & - & 89 & 89 & \\
\hline (5) & 作用底力 & 80 & $\begin{array}{l}\mathrm{R}: 1300 \\
\mathrm{C}: \quad 60 \\
\end{array}$ & 1230 & 1230 & \\
\hline (6) & 重 & $60\left(0.2 \mathrm{mi}^{\circ}\right)$ & $\begin{array}{l}R:{ }^{40} \\
C: 580 \\
\end{array}$ & 70 & 25 & \\
\hline (7) & 発生 $\left(\infty_{2}, \mathrm{l} \cdot \mathrm{C}\right)$ & 6 & 52 & 25 & 23 & \\
\hline (8) & 便益（䀦年) & $\begin{array}{l}5 \times 20 \\
100 \\
\end{array}$ & $\begin{array}{l}5 \times 40 \\
200 \\
\end{array}$ & $\begin{array}{l}5 \times 40 \\
200 \\
\end{array}$ & $\begin{array}{l}5 \times 40 \\
200 \\
\end{array}$ & \\
\hline 2 & C.S. $(\mathbf{N} / \theta)$ & 18 & 4 & 8 & 9 & \\
\hline (1) & 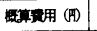 & 17,500 & 10.400 & 4,200 & 30,000 & \\
\hline
\end{tabular}

表- 6 b 例題 $1 \mathrm{~B}$ ：スパン $10.0 \mathrm{~m}$ の単純梁の二酸化炭素発生量及びC

\begin{tabular}{|c|c|c|c|c|c|c|}
\hline & \$1 $\quad * 4$ & 1. $\quad 14$ & 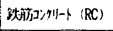 & 跌 却 (S) & アルミニウム & 满 \\
\hline D & 忉斦 & かかっつ。くまつ & $\begin{array}{l}\mathrm{R}: \mathrm{SD} 295 \\
\mathrm{C}: \because \cdot \mathrm{K}=240\end{array}$ & $S S 400$ & - & 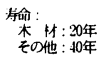 \\
\hline (2) & 汻容视力 $(w / d)$ & 95 & $\begin{array}{l}\mathrm{R}: 2000 \\
\mathrm{C}:\end{array}$ & 1600 & 1340 & \\
\hline (3) & 粉面 (an) & (젼] & 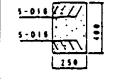 & {$\left[\frac{1}{i 10}\right]$} & $\perp_{1,150}$ & \\
\hline (4) & 粉面俰数 (cm) & 6667 & - & 324 & 481 & \\
\hline (5) & 作用纯力 $(1 / d)$ & 75 & $\begin{array}{l}\mathrm{R}: 1660 \\
\mathrm{C}:\end{array}$ & 1540 & 1040 & \\
\hline (6) & 重 $(\mathrm{kg})$ & $300(1 \mathrm{~m})$ & $\begin{array}{l}\mathrm{R}: 160 \\
\mathrm{C}: 2300\end{array}$ & 300 & 130 & \\
\hline (7) & 哞生 $\left(\infty_{2} k-c\right)$ & 29 & 208 & 105 & 117 & \\
\hline 8 & 便益 (四-年) & $\begin{array}{l}10 \times 20 \\
200\end{array}$ & $\begin{array}{c}10 \times 40 \\
400\end{array}$ & $\begin{array}{c}10 \times 40 \\
400\end{array}$ & $\begin{array}{c}10 \times 40 \\
400\end{array}$ & \\
\hline (2) & c.S. $(1 / 0)$ & 7 & 2 & 4 & 3.5 & \\
\hline (1) & 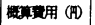 & 98.800 & 41,400 & 18,000 & 156,000 & \\
\hline
\end{tabular}




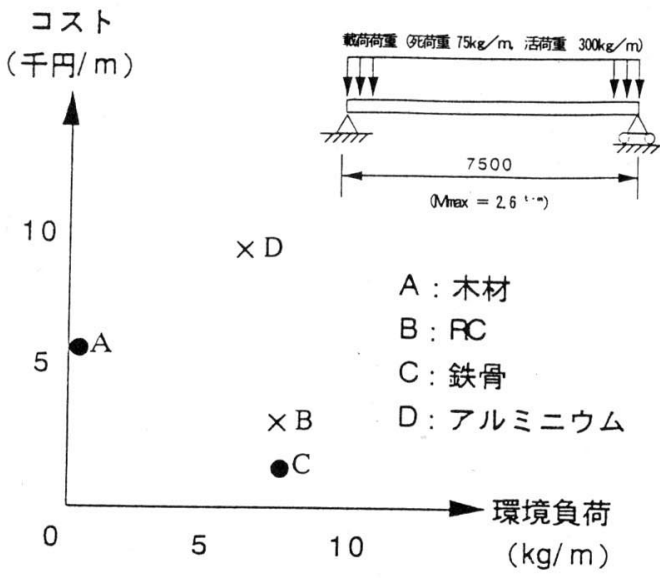

冈-10 例題 1 : 単純梁の費用と環境負荷（炭素換算 $\mathrm{CO}_{2}$ 排 出量)

り最大のC S を与える材料が変化しているなど, いろいろ多様な比較ができ，実際の計画・設計に C S を導入することの有効性を示している.

なお，この例題では問題が単純化されており， 梁を支える柱（あるいは橋脚）の構造を計算に入 れていないこと，建設時の環境負荷のみ対象にし ており維持管理や廃棄の負荷を無視していること, 材料の寿命を木材で20年，その他の材料で40年と した点, 荷重を単純化していること, および材料 の応力だけで断面を決定し，変位についての検討 は行っていないことなど，実際の設計とは異な る.

\section{（2）埋立護岸の設計代替案の選択の例}

水深 $4 \mathrm{~m}$, 海底面下 $10 \mathrm{~m}$ の粘性土地盤上に, 海底 面より $5 \mathrm{~m}$ 高さの埋め立てを行うための護岸を設計 する問題を考える。このケースでは，埋立を排水 したドライな状態で行うことを想定しているので， 護岸は止水性を有している必要がある.

紙面の制約のため詳細を示すことはできないが, 二重鋼矢板式, 鋼製セル式, ジャケット式, ケー ソンと止水壁を組み合わせた形式, 捨石と自立鋼 矢板を組み合わせた形式の 5 つの形式が, 設計代 替案として検討された。

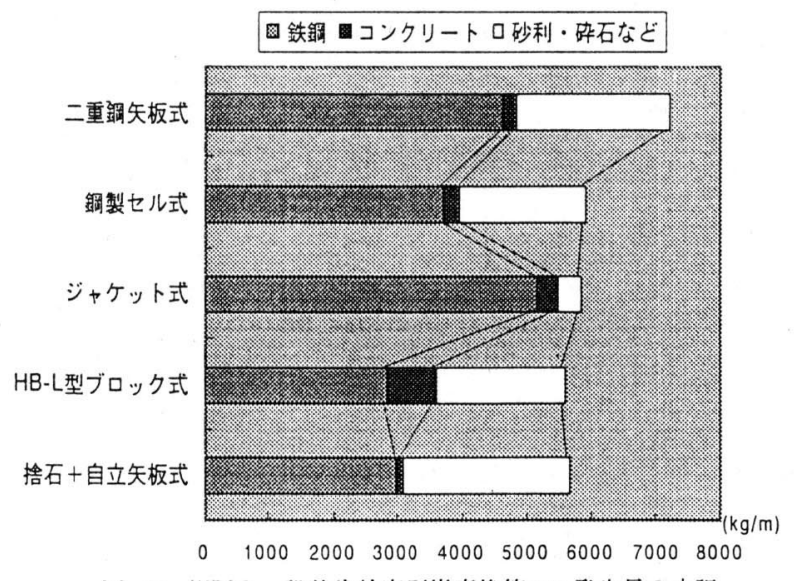

冈-11 例題 2 : 設計代替案別炭素換算 $\mathrm{CO}_{2}$ 発生量の内訳

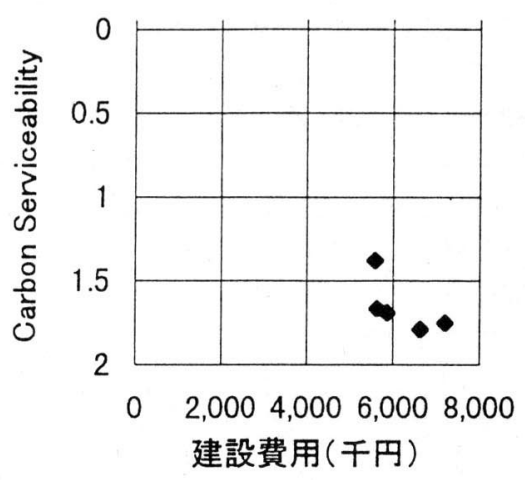

冈-12 例題 2 : 護岸建設費用とC S

表一 7 に，それぞれの設計案で計算された法線 $1 \mathrm{~m}$ 当りの建設費用と, 先の表一 3 を基に計算した 炭素排出量を示した. また，このとき法線 $1 \mathrm{~m}$ 当り 護岸が提供するサービスを1とすれば，C S は炭素 排出量の逆数となり,これも表一 7 に合わせて示 した.

ところで, 各設計案で計算された炭素排出量の おおよその内訳を示したのが，図一１1である.

鉄鋼，コンクリートなど二酸化炭素を多く発生さ せる製造工程を持つ材料の使用の多い設計案が炭 素の発生量が大きいと言えるが，捨て石堤など， 単位発生量の少ない材料を使用する案でも, 使用 量が多くなると結果的には大きな発生量となるこ とが分かる. 
表-7 例題 2 : 護岸の設計代替案の建設費, $\mathrm{CO}_{2}$ 排出量と換算総費用

\begin{tabular}{|c|c|c|c|c|}
\hline 設計代替案 & 建設費用（千円/m） & 炭素発生量 (kg-c/m) & C S $\left(\#-t^{\prime \prime} \pi / \mathrm{kg}-\mathrm{C} / \mathrm{m}\right)$ & 換算総建設費用（千円/m） \\
\hline 二重銅矢板式 & 5.580 & 7,200 & 1. $38 \times 10^{-4}$ & 5,594 \\
\hline 銅性セル式 & 5,860 & 5,900 & 1. $60 \times 10^{-4}$ & 5,872 \\
\hline ジャケシト式 & 5,620 & 6,000 & 1. $67 \times 10^{-4}$ & 5,740 \\
\hline ケーソン+止水壁式 & 6,630 & 5,600 & 1. $70 \times 10^{-4}$ & 6.742 \\
\hline 捨て石＋自立鎆矢板式 & 7,200 & 5,700 & 1. $75 \times 10^{-4}$ & 7,211 \\
\hline
\end{tabular}

园ー12に，各設計案の建設費用とC S をこれ らを軸とするグラフに示した. この図から分かる ように 5 個の代替案の内 4 個はパレート最適解で ある. すなわち，この中の任意の 2 個の案を比較 したとき，2つの評価規準（建設費用とC S ）の どちらかは一方が優れており，他方はもう一方が

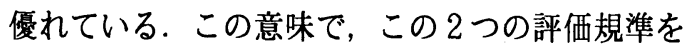
独立に考慮する場合，これら2つの案のどちらが 優れているとはいえない（無差別である）。

この例題で, 表4の定式化 I をとり, 現在最低の 建設費用である，二重鋼矢板式護岸の炭素発生量， $7,200 \mathrm{~kg} / \mathrm{m}$ の $80 \%$ の発生量に押さえることが要求 されていると仮定すると，この時のC S は，7， $200 \times 0.8=5,760$ の逆数 $1.74 \times 10^{-4}$ 以上の設計案が 選ばれなければならない。この中で，建設費用が 最小なのはケーソン十止水壁護岸であり，これが 選択される．なお，このときこれらの設計代替案 はすべて同じ設計条件で同じ設計基準を用いて設 計されているので, 破壊確率はほぼ等しく, 構造 物の信頼性に関する制約は同程度に満足されてい るとした。

一方, 定式化IIをとり, 仮に炭素1 $\mathrm{t}$ 当りの環境 負荷換算率を 2 千円（=約US\$20）としたとき，建 設費之環境負荷換算費の合計金額は，表-7の最 後の列に示した通りとなる ${ }^{18)}$. 期待破壊費用は同じ と考えられるので計算に考虑していない.このと きは二重鋼矢板式が最適解となった。

最後に, 定式化IIIの場合は, 先に述べたように 4 つの代替案がパレート最適解となり，この中か ら一つの最適解を決定することは，このような多 目的計画法ではできない.

\section{6. むすひ}

本研究では，これから我々が直面するであろう 資源・環境の制約を踏まえたうえでの社会基盤の 整備の問題を，社会基盤施設の設計法という立場
から捉え，そのアプローチの方向を示すことを目 的とした.

この問題を考える前提として，人類の経済活動 の大規模化にともない，従来それに資源を提供し， また廃棄物を受容していた自然システムが，もは や無限の容量を持つとは考えられなくなったこと を示した. そして，我々の経済活動を従来のよう に経済システム内の金銭と財の循環としてだけ捉 えるのではなく，自然システムをも含めた枠の中 で，物質収支を分析することが必要であることを 述べた. しかし，我々の知識の不足と，自然シス テムの複雑さのため，すべての物質の収支を追う ことは現時点では不可能である.

以上のような理解に基づき，我々は社会基盤施 設の設計法に物質収支と言う観点を考慮した指標 を，従来から考慮されてきた経済性と信頼性と言 う指標に加えるため, 当該構造物の環境負荷をお おまかに測る現実的な指標として，二酸化炭素発 生量をとることを提案した. 各構造物の建設・維 持管理・廃棄のときに発生する二酸化炭素量は， 各構成材料の二酸化炭素発生原単位を積み上げる ことにより計量される.さらに，一単位二酸化炭 素により得られるサービスを表す指標として， Carbon Serviciability（C S ) を提案した.

提案した設計法では, 設計代替案を評価する指 標として構造物の建設費用と信頼性に加えて二酸 化炭素発生量（すなわちC S ）を加えている.こ のため設計代替案の選択の問題は，多目的決定法 の問題となる. 我々はここに3つの定式化を示し たが，これらは決定的なものではなく将来にわた り改良を重ねて行く必要がある。最後に簡単な例 題を加え, 説明の一助とした.

今後の課題は数多い. そのいくつかを列挙する と,

1)経済性，信頼性，環境負荷と言う3つの指標 を持つ意思決定問題としての設計法の, 決定の合 理的な方法を研究する必要がある.

2)環境負荷として二酸化炭素発生量に基づく指 
標（例えばC S ）をとる場合でも，この発生や固 定を支配するメカニズムのより詳細な把握が必要 である.

3)物質収支と言う観点から見れば，二酸化炭素 だけの収支を考慮するだけでは不十分である．他 の物質の収支も，モデルに付加して行かなければ ならない.

この外にも，多くの解決されなけらばならない 問題点があるであろうが, もはや我々の経済活動 を取り囲み支える自然システムの容量をあたかも 無限であるように考える従来からの社会基盤施設 の設計法は十分ではなく，このような環境負荷か ら来る制約を考虑せざるをえないことに疑いの余 地はない。

著者らは，21世紀の社会基盤施設の設計では， 従来の経済性と安全性の尺度に加え, 環境負荷や エネルギー使用量を評価尺度として取り入れなけ ればならなくなると信じている.

謝辞： 本論文に示した研究成果は, 本論文の筆 頭著者が座長を勤めた私的研究グループ, 「エネ ルギー使用量を考慮した新しい設計法の開発研究 会」（活動期間1993年6月から1996年4月）での活 動の成果の一部である.ここに著者ら以外の構成 メンバーの名前を列挙し，その労に感謝したい. 小澤良夫, 矢木康照, 玉木勝平, 梅崎邦男, 鷹羽 信勝, 西嶋善昭, 林良嗣, 大塚悟, 中野正樹, 奥 野隆明, 山田英司の諸氏. また, 例題の計算では 1996年岐阜大学卒業生, 石倉宙, 魚住研司両君の 協力を受けた.

\section{参考文桬}

1) 厚生省人口問題研究所: 世界人口推計の概要, 研究資料 267 号, 1991.

2) 綿引邦彦 : 地球一この限界, オーム社, 1995.

3）通産省編 : エネルギー' $93 ， 1993$.

4) 環境庁編 : 平成 6 年度環境白書 : 環境への負荷の少ない社 会経済活動に向けて，1995.

5) 環境庁 UNC E D 報告, 1992.

6) 松尾稳 : 地盤工学一信頼性設計法の理論と実際一, 技報堂出 版, 1983.

7) 酒井寛二, 漆崎昇 : 建設業の資源消費量之環境負荷の推定, 第5回環境研究発表会論文，環境情報科学21-1, pp.130-
135, 1992.

8) 外岡豊，河中俊 : 産業連関表による建設部門誘発 $\mathrm{C} \mathrm{O} 2$ 排出 量の解析, IBS研究報告30周年記念号, pp.86-103，(財) 計 量計画研究所, 1995.

9) Yamamoto, R.: An introduction to LCA from the viewpoints of sustainable development and conservation of biosphere, Proc. of International Conference on Eco -Balance, Tsukuba,pp.1-2, Japan, 1995.

10) Boustead, I.: What can we do with LCA?, Proc. of International Conference on EcoBalance, pp.3-8, Tsukuba, Japan, 1995.

11) Gotoh, S.: Methodology for Assessing Environmental Load, Proc. of International Conference on EcoBalance, Tsukuba, pp.9-14, Japan, 1995.

12) Ikaga, T. and Ishifuku, A.: Evaluation of building design using Life Cycle $\mathrm{CO}_{2}$ analysis, Proc. of International Conference on EcoBalance, pp.119-124, Tsukuba, Japan, 1995.

13) Okada, T. and Koizumi, Y.: Practical application of the Life Cycle Assessment theory to construction, Proc. of International Conference on EcoBalance, pp.125-130, Tsukuba, Japan, 1995.

14) 植木和弘, 落合仁司, 北畠佳房, 寺西俊一 : 環境経済学, 有斐閣, 1991.

15) 宮沢健一編 : 産業連関分析入門一新版一, 日経文庫(508), 1995.

16）伊香賀俊治：1985年産業連関表に基づくC O 2 原単位, 日 本建築学会ライフサイクルC O2小委員会資料, 1994.

17) 建設省土木研究所 : 資源・エネルギー消費・環境負荷の算 定手法の開発と実態調査報告書, 1993.

18) Pearce, D.W., W.R.Cline, A.N.Achanta, S.Fankehauser, R.K.Pchauri, R.S.J. Tol and P.Vellinga: Chapter 6 The social cost of climate dhange; Greenhouse damage and the benefits of contral, IPCC Working Group III Report, 1995.

（1996.8.22受付） 